\title{
Article \\ Elemental and Speciation Analyses of Different Brands of Yerba Mate (Ilex paraguariensis)
}

\author{
Jędrzej Proch (D), Aleksandra Orłowska (D) and Przemysław Niedzielski *(D)
}

Department of Analytical Chemistry, Faculty of Chemistry, Adam Mickiewicz University, Uniwersytetu Poznańskiego 8, 61-614 Poznań, Poland; jedrzej.proch@amu.edu.pl (J.P.); aleksandra.orlowska@amu.edu.pl (A.O.)

* Correspondence: pnied@amu.edu.pl

\begin{abstract}
In this work, a methodology for determination of As(III), As(V), dimethylarsinic acid (DMA), Fe(II) and Fe(III) in fifty-eight samples (forty-nine products of thirteen brands from three countries) commercial yerba mate (Ilex paraguariensis) was performed. The hyphenated high performance liquid chromatography inductively coupled plasma optical emission spectrometry (HPLC-ICP OES) technique was used. Arsenic was determined below the quantification limit in 38 samples of yerba mate. As(III) was found at the level 0.09 and $0.08 \mathrm{mg} \mathrm{kg}^{-1}$. The As(V) content was in the range: 0.21 to $0.28 \mathrm{mg} \mathrm{kg}^{-1}$. The content of DMA was found the highest of the three arsenic species in the range: 0.21 to $0.47 \mathrm{mg} \mathrm{kg}^{-1}$. The content of $\mathrm{Fe}(\mathrm{II})$ and $\mathrm{Fe}(\mathrm{III})$ was found in the range: 0.61 to $15.4 \mathrm{mg} \mathrm{kg}^{-1}$ and 0.66 to $43.1 \mathrm{mg} \mathrm{kg}^{-1}$, respectively and the dominance of $\mathrm{Fe}(\mathrm{III})$ was observed. Moreover, total and extractable content of 16 elements were determined. The results have been subjected to statistical analysis in order to establish relationships between samples of the same origin (country), kind (type) and composition (purity).
\end{abstract}

Citation: Proch, J.; Orłowska, A.; Niedzielski, P. Elemental and Speciation Analyses of Different Brands of Yerba Mate (Ilex paraguariensis). Foods 2021, 10, 2925 https://doi.org/10.3390/ foods10122925

Academic Editor: Amin Mousavi Khaneghah

Received: 27 October 2021

Accepted: 23 November 2021

Published: 26 November 2021

Publisher's Note: MDPI stays neutral with regard to jurisdictional claims in published maps and institutional affiliations.

Copyright: (c) 2021 by the authors. Licensee MDPI, Basel, Switzerland. This article is an open access article distributed under the terms and conditions of the Creative Commons Attribution (CC BY) license (https:// creativecommons.org/licenses/by/ $4.0 /)$.
Keywords: yerba mate (Ilex paraguariensis); speciation analysis; essential trace elements; potentially toxic elements; hyphenated systems; ICP OES

\section{Introduction}

Yerba mate (Ilex paraguariensis St. Hil.) is a native South American tree. It is an important commercial product, consumed in the largest quantities in Brazil and Uruguay, while Argentina is the largest exporter [1]. The consumption of yerba mate has expanded to different countries e.g., Spain, France, Italy, Germany, Korea, Japan, Syria, Russia, United States and Australia [2]. Yerba mate can accumulate both essential trace and potentially toxic elements (PTEs) [1] and their content depends on certain factors, such as soil type, exposure of plants to pollution, even harvest season [3]. High tolerance to metals or metalloids has evolved in a number of plant species. Tolerant plants are often excluders, limiting the entry and translocation, or rarely hyperaccumulators combines extremely high tolerance to, and foliar accumulation of, trace elements [4].

Nowadays (2021), the determination of the total concentration of trace elements in yerba mate or its tea is not enough to evaluate the nutritional or toxic potential of the product. In infusions and decoctions, metals and metalloids may exist as either simple or complexed ions. This fact can affect the bioavailability of elements by humans [5]. What is more, nutritional and toxic potential depends on the element species, therefore a speciation analysis of elements, such as As, $\mathrm{Cr}$, Fe, Se is crucial. The toxicity of elements forms is significantly different, and the greatest obstacle to the efficient determination of these forms is the ease of converting from one form to another [6,7]. In opposite to arsenic, iron $(\mathrm{Fe})$ is an essential trace and the fourth most abundant element in the Earth's crust. Two main species, $\mathrm{Fe}(\mathrm{II})$ and $\mathrm{Fe}(\mathrm{III})$, are thermodynamically stable and kinetically reactive, however the role and the demand of these forms in living organisms are different [8]. Due to ambiguous classification of this material in the literature (as tea [9], laboratory plant [10] or wild-growing plant [11]), yerba mate (Ilex paraguariensis) is widely used by 
authors as an application material for new analytical methods [1,5,12-17]. It is surprising that the content of essential trace and potentially toxic elements in yerba mate have been obtained by ICP OES [18], ICP MS [1,19] or both ICP OES and ICP MS [11,20], excluding any speciation studies. Admittedly, some methods for determining the species of selenium [14], arsenic [12], iron [13], as well as iron and arsenic [17] in several samples of yerba mate have already been presented. However, speciation studies have not yet been carried out on a larger number of samples.

In this study, to investigate the speciation of arsenic and iron in yerba mate (Ilex paraguariensis), 58 samples were collected from the Polish market. Additionally, the determination of selected essential trace and potentially toxic elements (PTEs), i.e., Al, As, $\mathrm{Cd}, \mathrm{Co}, \mathrm{Cr}, \mathrm{Cu}, \mathrm{Fe}, \mathrm{Hg}, \mathrm{Li}, \mathrm{Mn}, \mathrm{Mo}, \mathrm{Ni}, \mathrm{Pb}, \mathrm{Sb}$, Se and $\mathrm{Zn}$, was performed using ICP OES. The determination of $\mathrm{As}(\mathrm{III}), \mathrm{As}(\mathrm{V})$ and DMA as well as Fe(II) and Fe(III) in yerba mate is a novel, although it is an enlargement of the preliminary studies, conducted for the first usage of HPLC-HG-ICP OES with MSIS as an interface [12], the first comparison of HPLC-MIP OES and HPLC-ICP OES [13], and the first combination of two HPLC systems with ICP OES through MSIS (2 HPLC-MSIS-ICP OES) [17].

\section{Materials and Methods}

\subsection{Samples Collecting}

Fifty-eight samples of forty-nine yerba mate products from thirteen brands were bought from legal stores located in Poland. Samples were originated from Argentina $(n=15)$, Brazil $(n=23)$, and Paraguay $(n=18)$, however most of samples $(n=33)$ were repackaged in Poland (and distributed under a Polish trademark). According to kind (type), 30 samples were "con palo" (a mixture of 70\% leaves and 30\% stalks) and 26 samples were "despalada" (a mixture of 90\% leaves and 10\% stalks). According to composition (purity), 34 samples contained some additives (Table 1) and 24 samples were pure yerba mate. Additionally, nine products (A1, B5, B7, D1, D2, D3, D4, F3, H1) were collected twice (as a $50 \mathrm{~g}$ test sample and a $500 \mathrm{~g}$ pack). Full details were shown in Table 1.

Table 1. Details of samples' characteristics.

\begin{tabular}{|c|c|c|c|c|c|}
\hline Sample No. & Product Code & Country of Origin & Type (Kind) & Additives & Packing Type (Weight) \\
\hline 1 & A1 & Argentina & Con palo & - & a pack $(500 \mathrm{~g})$ \\
\hline 2 & A1 & Argentina & Con palo & - & a test sample (50 g) \\
\hline 3 & A2 & Argentina & Con palo & - & a test sample (50 g) \\
\hline 4 & A3 & Argentina & Despalada & - & a pack $(500 \mathrm{~g})$ \\
\hline 5 & A4 & Argentina & Con palo & - & a pack $(500 \mathrm{~g})$ \\
\hline 6 & A5 & Argentina & Despalada & - & a pack $(500 \mathrm{~g})$ \\
\hline 7 & B1 & Paraguay * & Con palo & - & a test sample (50 g) \\
\hline 8 & B2 & Paraguay * & Con palo & - & a test sample (50 g) \\
\hline 9 & B3 & Paraguay * & Con palo & aromas & a test sample (50 g) \\
\hline 10 & B4 & Paraguay * & Despalada & - & a test sample (50 g) \\
\hline 11 & B5 & Paraguay * & Con palo & aromas & a pack $(500 \mathrm{~g})$ \\
\hline 12 & B5 & Paraguay * & Con palo & aromas & a test sample (50 g) \\
\hline 13 & B6 & Paraguay * & Con palo & herbs & a test sample (50 g) \\
\hline 14 & B7 & Paraguay * & Con palo & herbs & a pack (500 g) \\
\hline 15 & B7 & Paraguay * & Con palo & herbs & a test sample (50 g) \\
\hline 16 & $\mathrm{C} 1$ & Brazil * & Despalada & - & a test sample (50 g) \\
\hline 17 & $\mathrm{C} 2$ & Brazil * & Despalada & fruits, aromas & a test sample (50 g) \\
\hline 18 & $\mathrm{C} 3$ & Brazil * & Despalada & fruits, herbs, aromas & a test sample (50 g) \\
\hline 19 & $\mathrm{C} 4$ & Brazil * & Despalada & fruits, flowers, herbs & a test sample (50 g) \\
\hline 20 & C5 & Brazil * & Despalada & herbs, fruits, aromas & a test sample (50 g) \\
\hline 21 & C6 & Brazil * & Despalada & flowers, herbs, seeds, aromas & a test sample (50 g) \\
\hline 22 & $\mathrm{C} 7$ & Brazil * & Despalada & fruits, flowers, aromas & a test sample (50 g) \\
\hline 23 & $\mathrm{C} 8$ & Brazil * & Despalada & fruits, aromas & a test sample (50 g) \\
\hline 24 & C9 & Brazil * & Despalada & herbs, fruits, aromas & a test sample (50 g) \\
\hline 25 & $\mathrm{C} 10$ & Brazil * & Despalada & herbs, fruit skin, aromas & a test sample (50 g) \\
\hline 26 & $\mathrm{C} 11$ & Brazil * & Despalada & fruit skin, herbs, aromas & a test sample (50 g) \\
\hline 27 & $\mathrm{C} 12$ & Brazil * & Despalada & fruits, flowers, aromas & a test sample (50 g) \\
\hline 28 & D1 & Paraguay & Con palo & - & a pack (500 g) \\
\hline 29 & D1 & Paraguay & Con palo & - & a test sample (50 g) \\
\hline 30 & D2 & Paraguay & Con palo & - & a pack (500 g) \\
\hline
\end{tabular}


Table 1. Cont

\begin{tabular}{|c|c|c|c|c|c|}
\hline Sample No. & Product Code & Country of Origin & Type (Kind) & Additives & Packing Type (Weight) \\
\hline 31 & D2 & Paraguay & Con palo & - & a test sample (50 g) \\
\hline 32 & D3 & Paraguay & Con palo & aromas & a pack $(500 \mathrm{~g})$ \\
\hline 33 & D3 & Paraguay & Con palo & aromas & a test sample (50 g) \\
\hline 34 & D4 & Paraguay & Con palo & herbs & a pack $(500 \mathrm{~g})$ \\
\hline 35 & D4 & Paraguay & Con palo & herbs & a test sample (50 g) \\
\hline 36 & E1 & Brazil * & Despalada & - & a test sample (50 g) \\
\hline 37 & E2 & Brazil * & Despalada & fruits, herbs, flowers, aromas & a test sample (50 g) \\
\hline 38 & E3 & Brazil * & Despalada & herbs, fruit skin, aromas & a test sample (50 g) \\
\hline 39 & $\mathrm{E} 4$ & Brazil * & Despalada & fruits, aromas & a test sample (50 g) \\
\hline 40 & E5 & Brazil * & Despalada & herbs, fruits, aromas & a test sample (50 g) \\
\hline 41 & E6 & Brazil * & Despalada & fruits, herbs, aromas & a test sample (50 g) \\
\hline 42 & E7 & Brazil * & Despalada & fruit skin, aromas & a test sample (50 g) \\
\hline 43 & E8 & Brazil * & Despalada & fruits, herbs, flowers, aromas & a test sample (50 g) \\
\hline 44 & E9 & Brazil * & Despalada & fruits, flowers, aromas & a test sample (50 g) \\
\hline 45 & E10 & Brazil * & Despalada & herbs, flowers, aromas & a test sample (50 g) \\
\hline 46 & $\mathrm{~F} 1$ & Argentina & Con palo & - & a pack $(500 \mathrm{~g})$ \\
\hline 47 & $\mathrm{~F} 2$ & Argentina & Con palo & - & a pack (500 g) \\
\hline 48 & F3 & Argentina & Con palo & - & a pack (500 g) \\
\hline 49 & F3 & Argentina & Con palo & - & a test sample (50 g) \\
\hline 50 & G1 & Argentina & Con palo & - & a test sample (50 g) \\
\hline 51 & H1 & Argentina & Con palo & - & a test sample (50 g) \\
\hline 52 & H1 & Argentina & Con palo & - & a pack $(500 \mathrm{~g})$ \\
\hline 53 & $\mathrm{H} 2$ & Argentina & Con palo & aromas & a test sample (50 g) \\
\hline 54 & $\mathrm{I} 1$ & Paraguay & Con palo & - & a test sample (50 g) \\
\hline 55 & $\mathrm{~J} 1$ & $\mathrm{~N} / \mathrm{D} *$ & $\mathrm{~N} / \mathrm{D}$ & fruits, flowers, herbs & a weighted pack (100 g) \\
\hline 56 & K1 & Brazil & Despalada & - & a test sample $(50 \mathrm{~g})$ \\
\hline 57 & L1 & Argentina & Con palo & herbs, aromas & a pack $(500 \mathrm{~g})$ \\
\hline 58 & M1 & $\mathrm{N} / \mathrm{D} *$ & $\mathrm{~N} / \mathrm{D}$ & fruit skin, fruits & a weighted pack (100 g) \\
\hline
\end{tabular}

The Latin letter means the brand (A-M), and the following Arabic number means the same product; * means repacked in Poland and distributed as the Polish trademark; N/D means no data.

\subsection{Gases and Reagents}

High-pure argon (N-5.0, purity 99.999\%), obtained from Linde, Poland, was employed as a plasma gas. All solutions were prepared using deionized water $(\geq 18 \mathrm{M} \Omega$ $\mathrm{cm}$ resistivity, water purification system Milli-Q (Merck Millipore, Darmstadt, Germany)). Standard solutions were prepared from commercially available ICP calibration standards (Romil, Cambridge, UK). Disodium hydroarsenate hepahydrate, sodium arsenite and cacodylic acid were collected from Sigma-Aldrich (Saint Louis, MO, USA). Ferric ammonium sulfate dodecahydrate and ferrous ammonium sulfate hexahydrate were obtained from Acros-Thermo Fisher Scientific (Geel, Belgium). Standard solutions of iron and arsenic (1000 mg L ${ }^{-1}$ ) were prepared by dissolving appropriate amounts of chemical compound in water. Less concentrated standard solutions obtained by dilution of the stock solutions were prepared daily. $1 \mathrm{~mol} \mathrm{~L}-1$ orthophosphoric acid was prepared from $85 \% \mathrm{H}_{3} \mathrm{PO}_{4}$ $\left(\mathrm{POCH}^{\mathrm{TM}}\right.$, Avantor ${ }^{\circledR}$, Gliwice, Poland). $65 \%$ nitric acid $\left(\mathrm{HNO}_{3}\right)$ was obtained from Merck.

A phosphate buffer was prepared by mixing disodium hydrophosphate $\left(\mathrm{Na}_{2} \mathrm{HPO}_{4}\right)$ and potassium dihydrophosphate $\left(\mathrm{KH}_{2} \mathrm{PO}_{4} \cdot 2 \mathrm{H}_{2} \mathrm{O}\right)$ obtained from Merck. Appropriate amounts of powder reagents were dissolved and mixed to obtain the mobile phase solution, $25 \mathrm{mmol} \mathrm{L}^{-1} \mathrm{KH}_{2} \mathrm{PO}_{4} \cdot 2 \mathrm{H}_{2} \mathrm{O}$ and $2.5 \mathrm{mmol} \mathrm{L}-1 \mathrm{Na}_{2} \mathrm{HPO}_{4}$ (pH adjusted to $6.0 \pm 0.2$ ). $1.0 \%$ $(w / v)$ sodium tetrahydroborate $\left(\mathrm{NaBH}_{4}\right)$, was prepared daily, by dissolving appropriate amounts of powdered $\mathrm{NaBH}_{4}$ (Sigma-Aldrich) in water and stabilized with $0.1 \%(w / v)$ $\mathrm{NaOH}$ (Merck). $5 \mathrm{~mol} \mathrm{~L}^{-1}$ hydrochloric acid was prepared from $30 \% \mathrm{HCl}$ (Suprapur ${ }^{\circledR}$, Merck). A PDCA eluent was prepared by mixing appropriate volumes of pyridine-2,6dicarboxylic acid (PDCA) and formic acid ( $\mathrm{HCOOH}$ (Sigma-Aldrich), then appropriate amounts of potassium hydroxide $(\mathrm{KOH})$ and potassium sulfate $\left(\mathrm{K}_{2} \mathrm{SO}_{4}\right)$ (Merck) were dissolved in deionized water. Molar concentrations of PDCA, $\mathrm{K}_{2} \mathrm{SO}_{4} \mathrm{KOH}$, and $\mathrm{HCOOH}$ were 7.0, 5.6, 66 and $74 \mathrm{mmol} \mathrm{L}^{-1}$ respectively (pH $\left.4.2 \pm 0.2\right) .100 \mathrm{mmol} \mathrm{L}^{-1}$ sodium sulfite (Merck) was obtained by dissolving appropriate amounts of powder $\left(\mathrm{Na}_{2} \mathrm{SO}_{3}\right)$ in water and the solution was used to the periodic column conditioning. 


\subsection{Sample Preparation}

Samples were homogenized using agate laboratory grinder (Pulverisette, Fritsch $\mathrm{GmbH}$, Idar-Oberstein, Germany). The procedure of ultrasound-assisted extraction was repeated after previous studies $[12,13,17]$. Accurately weighted $1.00( \pm 0.01) \mathrm{g}$ dry samples were placed in a polyethylene test tube. Then $8.0 \mathrm{~mL}$ of $1 \mathrm{~mol} \mathrm{~L}^{-1}$ orthophosphoric acid $\left(\mathrm{H}_{3} \mathrm{PO}_{4}\right)$ was added and the ultrasound-assisted extraction was conducted for $30 \mathrm{~min}$ at ambient temperature. Then samples were filtered through a paper filter, washed previously by $200 \mathrm{~mL}$ of water and $20 \mathrm{~mL}$ of phosphate buffer. Sample solutions were neutralized with a few drops of $15 \mathrm{~mol} \mathrm{~L}^{-1} \mathrm{NaOH}$ to obtain $\mathrm{pH}$ value in the range of 6.0 to 6.5 and filled up to the final volume of $10 \mathrm{~mL}$. Prepared extracts were tested using ICP OES (extractable content), HPLC-HG-ICP OES (arsenic speciation analysis) and HPLC-ICP OES (iron speciation analysis). Samples were analyzed daily or stored at $-30{ }^{\circ} \mathrm{C}$ in the laboratory (no longer than a week). Additionally, accurately weighted, $0.500( \pm 0.001) \mathrm{g}$ of dry samples, were digested with $5.0 \mathrm{~mL}$ of $65 \% \mathrm{HNO}_{3}$ in closed Teflon ${ }^{\circledR}$ containers $(55 \mathrm{~mL})$ using the microwave digestion system, Mars 6 (CEM, Matthews, NC, USA). The process was carried out in three stage: (1) ramping the temperature $(20 \mathrm{~min}),(2)$ holding at $180{ }^{\circ} \mathrm{C}$ (20 $\mathrm{min})$, (3) cooling (20 $\mathrm{min})$. After digestion, samples were diluted with deionized water to a final volume of $10 \mathrm{~mL}$. Digested samples were analyzed using ICP OES (total content of elements).

\subsection{Arsenic Speciation Studies Using HPLC-HG-ICP OES}

The hyphenated technique, HPLC-HG-ICP OES with multi-mode sample introduction system (MSIS, Agilent, Santa Clara, CA, USA) as an interface was previously described in details [12] and it was used to determine $\mathrm{As}(\mathrm{III}), \mathrm{As}(\mathrm{V})$ and DMA. Full experimental conditions of HPLC-HG-ICP OES were summarized in Table 2. The HPLC system was constructed from a HPLC pump, Shimadzu LC-10AT (Shimadzu, Kyoto, Japan) and an anion-exchange HPLC column, Supelco LC-SAX1, $250 \mathrm{~mm} \times 4.6 \mathrm{~mm}$ i.d., resin particle size $5 \mu \mathrm{m}$ (Supelco, Bellefonte, PA, USA). The outlet of the HPLC column was directly connected (avoiding the peristaltic pump) with the tube which supplied $\mathrm{HCl}$ using Tshape connecter. The hydride generation is possible due to inlets located vertically in the center of the MSIS unit. The upper inlet was used to provide $\mathrm{NaBH}_{4}$ solution. The lower inlet provided an eluent with sample solution and $\mathrm{HCl}, \mathrm{HG}$ reagents were mixed at the top of the inlets, volatile hydrides were formed and transported into ICP torch by argon (introduced by nebulizer gas inlet). A nebulizer sample inlet stayed blocked. The excess liquid was carried from the chamber using a peristaltic pump. The detector of the hyphenated technique was Agilent 5110 ICP-OES (Agilent). The sample was analyzed three times $(n=3)$. Instrument detection limits (DLs) were calculated using the background equivalent concentration (BEC) and the signal-to-background ratio (SBR). The BEC was calculated as BEC $=\mathrm{C}_{\text {standard }} / \mathrm{SBR}$, where $\mathrm{C}_{\text {standard }}$ is the concentration of reference standard solution; $\mathrm{SBR}=\left(\mathrm{I}_{\text {standard }}-\mathrm{I}_{\text {blank }}\right) / \mathrm{I}_{\text {blank }}$; and $\mathrm{I}_{\text {blank }}$ and $\mathrm{I}_{\text {standard }}$ are the emission intensities [cps] for the blank and the reference standard solution. The DL was calculated $\left(\mathrm{DL}=3 \times \mathrm{RSD}_{\text {blank }} \times \mathrm{BEC} / 100\right), \mathrm{RSD}_{\text {blank }}$ is the relative standard deviation of multiple $(n=10)$ blank measurements. Instrument quantification limits (QLs, calculated as $3.3 \times$ DL), were presented in Table 3 with the method quantification limits, which include a sample preparation. The standard addition method was used for traceability measurements. Recoveries were in the acceptable range (80-120\%) and full results were presented in Supplementary Materials (Table S1). The uncertainty estimated for complete analytical process (with sample preparation step) was below $20 \%$ 
Table 2. Operating conditions of HPLC-HG-ICP OES (arsenic speciation analysis), HPLC-ICP OES (iron speciation analysis) and ICP OES (total and extractable content).

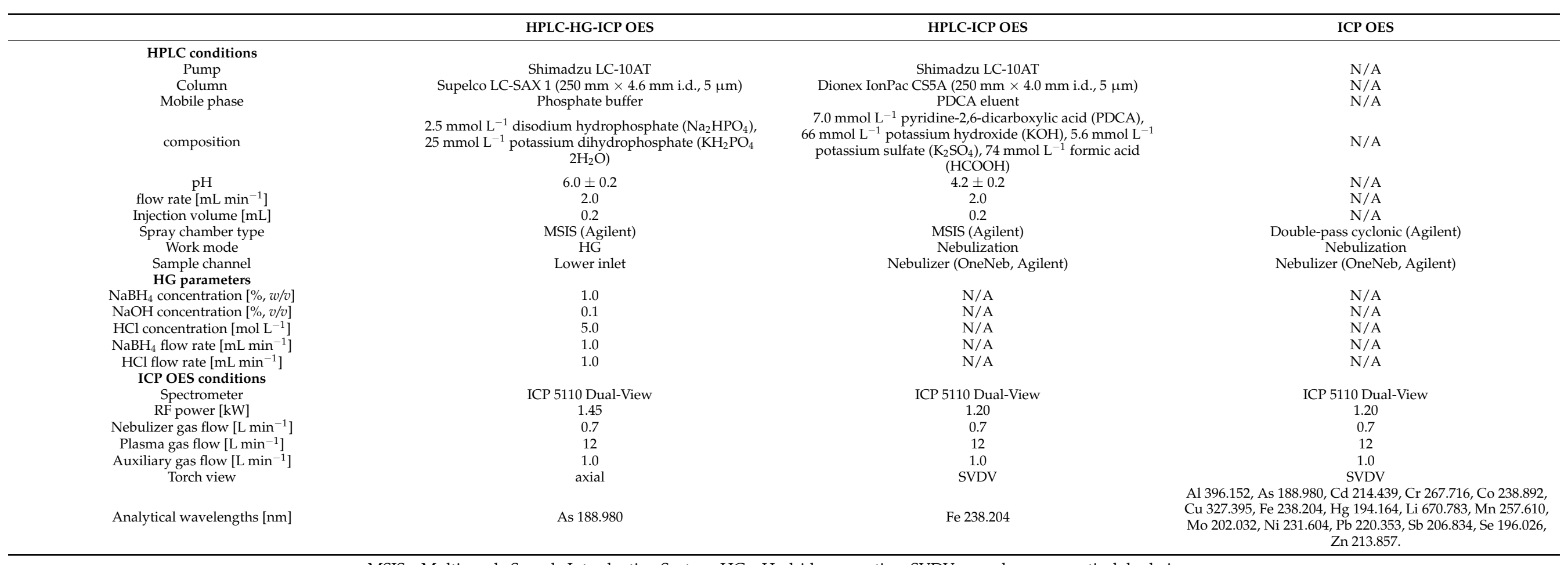

MSIS—Multi-mode Sample Introduction System; HG—Hydride generation; SVDV—synchronous vertical dual view.

Table 3. Instrument and method quantification limits (including a sample preparation procedure).

\begin{tabular}{|c|c|c|c|c|c|c|c|c|c|c|c|c|c|c|c|c|c|c|c|c|c|}
\hline & $\mathrm{Al}^{\mathrm{a}}$ & As $^{a}$ & $\operatorname{As}(\mathrm{IIII})^{\mathrm{b}}$ & $\operatorname{As}(V)^{b}$ & DMA $^{b}$ & $\mathrm{Cd}^{\mathrm{a}}$ & $\mathrm{Co}^{\mathrm{a}}$ & $\mathrm{Cr}^{\mathrm{a}}$ & $\mathrm{Cu}^{\mathrm{a}}$ & $\mathrm{Fe}^{\mathrm{a}}$ & $\mathrm{Fe}(\mathrm{II})^{\mathrm{c}}$ & $\mathrm{Fe}(\mathrm{IIII})^{\mathrm{c}}$ & $\mathrm{Hg}^{\mathrm{a}}$ & $\mathrm{Li}^{\mathrm{a}}$ & $\mathrm{Mn}^{\mathrm{a}}$ & $\mathrm{Mo}^{\mathrm{a}}$ & $\mathrm{Ni}^{\mathrm{a}}$ & $\mathrm{Pb}^{\mathrm{a}}$ & $\mathrm{Sb}^{\mathrm{a}}$ & $S e^{a}$ & $\mathrm{Zn}^{\mathrm{a}}$ \\
\hline $\mathrm{QL}\left[\mu \mathrm{g} \mathrm{L}^{-1}\right]$ & 9.3 & 18 & 6.2 & 21 & 19 & 0.5 & 0.7 & 0.6 & 0.5 & 6.7 & 36 & 30 & 4.0 & 0.3 & 5.8 & 1.5 & 5.0 & 12 & 17 & 7.0 & 1.6 \\
\hline $\mathrm{QL}(\mathrm{ext})\left[\mathrm{mg} \mathrm{kg}^{-1}\right]$ & 0.093 & 0.180 & 0.062 & 0.210 & 0.190 & 0.005 & 0.007 & $*$ & 0.005 & 0.067 & 0.360 & 0.300 & 0.040 & 0.003 & 0.058 & 0.015 & 0.050 & 0.120 & 0.170 & 0.070 & 0.016 \\
\hline $\mathrm{QL}\left(\right.$ total) $\left[\mathrm{mg} \mathrm{kg}^{-1}\right]$ & 0.190 & 0.360 & $\mathrm{x}$ & $\mathrm{x}$ & $\mathrm{x}$ & 0.010 & 0.014 & 0.012 & 0.010 & 0.134 & $\mathrm{x}$ & $\mathrm{x}$ & 0.080 & 0.006 & 0.116 & 0.030 & 0.100 & 0.240 & 0.340 & 0.140 & 0.032 \\
\hline
\end{tabular}

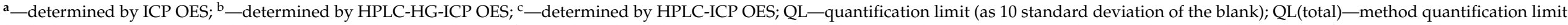
(including microwave-assisted digestion); QL(ext)—method quantification limit (including ultrasound-assisted extraction); $x$-not determined; * - not determined (due to interferences, details in text). 


\subsection{Iron Speciation Studies Using HPLC-ICP OES}

The hyphenated technique, HPLC-ICP OES was previously described in details [13] and it was used to determine Fe(II) and Fe(III). The HPLC system was made up of a Shimadzu LC-10AT HPLC pump and a Dionex IonPac CS5A cation-exchange HPLC column $(250 \mathrm{~mm} \times 4.0 \mathrm{~mm}$ i.d., resin particle size $5 \mu \mathrm{m}$, Thermo Fisher Scientific, Waltham, MA, USA). The outlet of the cation-exchange HPLC column was directly connected (avoiding the peristaltic pump) with the nebulizer sample inlets. Peristaltic pump of ICP-OES system was used to drain the waste only. MSIS was applied as a conventional cyclonic spray chamber with OneNeb nebulizer (both Agilent). The detector of the hyphenated technique was Agilent 5110 ICP-OES (Agilent). The operating conditions were placed in Table 2. The sample was analyzed 3 times $(n=3)$. All DLs and QLs were calculated as described in the Section 2.4 and the results were presented in Table 3. The standard addition method was used for accuracy studies. Recoveries were in the acceptable range (80-120\%) and full results were presented in Supplementary Materials (Table S1). The uncertainty for the complete analytical process (including a sample preparation) was at the level of $20 \%$.

\subsection{ICP OES Determination of Selected Elements Content}

An inductively coupled plasma optical emission spectrometer (Agilent 5110 ICP-OES) was used to determine selected elements ( $\mathrm{Al}, \mathrm{As}, \mathrm{Cd}, \mathrm{Co}, \mathrm{Cr}, \mathrm{Cu}, \mathrm{Fe}, \mathrm{Hg}, \mathrm{Li}, \mathrm{Mn}, \mathrm{Mo}, \mathrm{Ni}, \mathrm{Pb}$, $\mathrm{Sb}, \mathrm{Se}, \mathrm{Zn}$ ) in acid digests (total content) and extracts (extractable content). Synchronous vertical dual view (SVDV), which allows the axial and radial view analysis simultaneously, was used (viewing height for radial plasma observation was $8 \mathrm{~mm}$ ). Grading fixed optic was thermostated at $35^{\circ} \mathrm{C}$ and a detector, VistaChip II with the charge coupled device (CCD) was cooled to $-40^{\circ} \mathrm{C}$ using a triple Peltier system. The signal accusation time was $5 \mathrm{~s}$ for three replicates. The operating conditions were summarized in Table 2. The sample was analyzed three times $(n=3)$. All DLs and QLs were calculated as described in the Section 2.4 and the results are presented in Table 3. The standard addition method was used for traceability measurements. Recoveries were in the acceptable range (80-120\%) and full results were presented in Supplementary Materials (Tables S1 and S2). The uncertainty for the complete analytical process with sample preparation step was estimated at the level of $20 \%$.

\subsection{Statistical Analysis}

Statistical analyses were performed using computer software Statistica 13.3 (StatSoft, TIBCO Software Inc., Palo Alto, CA, USA). The distribution of the data was studied by the Kolmogorov-Smirnov, Lilliefors and Shapiro-Wilk tests. Given that the data did not follow a normal distribution, the Spearman's rank correlation coefficient, which is a nonparametric test, was used. The multidimensional statistical analysis (principal components analysis, PCA) was provided for the results of ICP OES analysis to indicate the individual differences in the elemental composition of the yerba mate samples. The probability value, $p=0.05$, was applied for all statistical tests.

\section{Results and Discussion}

\subsection{As and Fe Speciation Studies}

When examining the composition of yerba mate in terms of the content of selected forms of arsenic and iron, two methods of sample preparation were used prior to the ICP OES analysis: microwave-assisted digestion to determine As(total) and Fe(total), and ultrasound-assisted extraction to determine As and Fe extractable with phosphoric acid, i.e., As(ext) and Fe(ext). Then extracted samples were analyzed parallel by HPLC-HG-ICP OES determining the content of As(III), As(V) and DMA and HPLC-ICP OES determining the content of $\mathrm{Fe}(\mathrm{II})$ and $\mathrm{Fe}(\mathrm{III})$. The differences between the extractable content and the sum of arsenic or iron species were described as undefined As or Fe extractable forms, i.e., As(und-ext) and Fe(und-ext). Moreover, the differences between the total content and the extractable content were described as a non-extractable fraction of $\mathrm{As}$ and $\mathrm{Fe}$, i.e., 
As(non-ext) and Fe(non-ext). Results of arsenic and iron speciation studies were presented in Figure 1 as (a) the content of each fraction $\left(\mathrm{mg} \mathrm{kg}^{-1}\right)$ and (b) the percentage of each fraction in total content (as 100\%).

Arsenic was determined below the quantification limit (BQL) in 38 of the yerba mate samples. As(total) and As(ext) were found above quantification limit (AQL) in 20 and eight samples, respectively. As(ext) was determined BQL in 12 of 20 samples, therefore the content As(non-ext) was equal to As(total). In turn, As(III), As(V) and DMA were detected AQL only in two, four and four samples, respectively. Three arsenic species were only found AQL in one sample (no. 4), which was pure despalada from Argentina. As(III) was found at the similar level, 0.09 and $0.08 \mathrm{mg} \mathrm{kg}^{-1}$, in samples nos. 4 and 8, respectively. These samples also contained inorganic As (the sum of As(III) and As(V)) at the highest level, i.e., $0.36 \mathrm{mg} \mathrm{kg}^{-1}$. The $\mathrm{As}(\mathrm{V})$ content was in the narrow range, from 0.21 (no. 44) to $0.28 \mathrm{mg} \mathrm{kg}^{-1}$ (no. 8). The content of DMA was found in the range from 0.21 (no. 58) to $0.47 \mathrm{mg} \mathrm{kg}^{-1}$ (no. 12) and it was the highest of the three arsenic species. On one hand, the sum of three arsenic species represented the majority (80-98\%) of As(ext), except samples nos. 13 and 18, containing only undefined As extractable forms (As(und-ext)) at relatively low levels, 0.28 and $0.24 \mathrm{mg} \mathrm{kg}^{-1}$, respectively. On the other hand, the content of As(ext) was $29 \%$ (as median) of As(total).

The content of As(total) and As(ext) exceeded the recommended limit $\left(0.60 \mathrm{mg} \mathrm{kg}^{-1}\right)$, established by legislation [21], in 16 and two samples (nos. 4 and 53), respectively. Surprisingly, the mean value of As(total) $\left(1.35 \mathrm{mg} \mathrm{kg}^{-1}\right)$ was 26 [20], 28 [11,19] and 34 times higher $[1,22]$ than in the literature, however it was also found BQL in 38 samples. Additionally, it is difficult to clearly indicate whether the ultrasound-assisted extraction in $1 \mathrm{~mol} \mathrm{~L}^{-1} \mathrm{H}_{3} \mathrm{PO}_{4}$ (at room temperature) allows to extract its higher content than a traditional extraction in hot water $\left(80 \pm 10^{\circ} \mathrm{C}\right)$. Opinions are divided in the literature and the following percentage of total content were found in hot water, $18 \%$ [22], 48\% [20] and $49 \%$ [10]. Therefore, the risk of exceeding the recommended level cannot be directly assessed. The determination of three As species has not been performed on yerba mate samples yet, except the introduction as an application material for HPLC-HG-ICP OES [12] and 2 HPLC-MSIS-ICP OES [17], therefore no comparable data are available in the literature. In the first work, $\mathrm{As}(\mathrm{III}), \mathrm{As}(\mathrm{V})$ and DMA were found at lower ranges in six samples: $0.012-0.032 \mathrm{mg} \mathrm{kg}^{-1}, 0.046-0.108 \mathrm{mg} \mathrm{kg}^{-1}$ and $0.044-0.097 \mathrm{mg} \mathrm{kg}^{-1}$, respectively [12]. In the second work, only As(V) was determined in three samples $\left(0.31-0.33 \mathrm{mg} \mathrm{kg}^{-1}\right)$, while As(III) and DMA were found BQL in all samples $(n=8)$ [17]. Although results were rather comparable with those obtained in previous studies, occurring As and its species in yerba mate as well as occasionally the high content, are accidental rather than related to studied factors, i.e., country of origin and packing, kind or purity.

$\mathrm{Fe}$ (total) and $\mathrm{Fe}(\mathrm{ext})$ were found in the following ranges: $51.1-1059 \mathrm{mg} \mathrm{kg}^{-1}$ and $2.92-62.8 \mathrm{mg} \mathrm{kg}^{-1}$, respectively, in the whole sample population $(n=58)$. In the case of $\mathrm{Fe}$, it is difficult to clearly indicate whether the ultrasound-assisted extraction in $1 \mathrm{~mol} \mathrm{~L}^{-1}$ $\mathrm{H}_{3} \mathrm{PO}_{4}$ (at room temperature) allows one to extract a higher amount than a traditional extraction in hot water $\left(80 \pm 10^{\circ} \mathrm{C}\right)$. Opinions on this in the literature are divided and the following percentages of total content were found in hot water: 1.3\% [23], 2\% [22], 3\% [10] and $15 \%$ [20]. However, the percentage of extraction by cold water (1.1\%) was similar to hot water $(1.3 \%)$ [23], therefore a higher percentage of extraction may be obtained with the method proposed in this study, 8\% (as median). Ionic Fe(II) and Fe(III) were determined AQL in 26 and 31 samples respectively. The content of Fe(II) and Fe(III) was ranging, 0.61-15.4 $\mathrm{mg} \mathrm{kg}^{-1}$ and $0.66-43.1 \mathrm{mg} \mathrm{kg}^{-1}$, respectively. Although the Fe(III)/Fe(II) ratio was found in wide range $(0.3-33)$, the dominance of Fe(III) was observed (median $=2.7$ ). Higher content of Fe(II) was determined in four samples (nos. 6, 29, 37, 39). The highest content of Fe(II) and Fe(III) was detected in samples nos. 11 and 9, respectively, which were both Paraguayan yerba mate con palo with additives (aromas) and distributed under the same Polish brand (Table 1). 

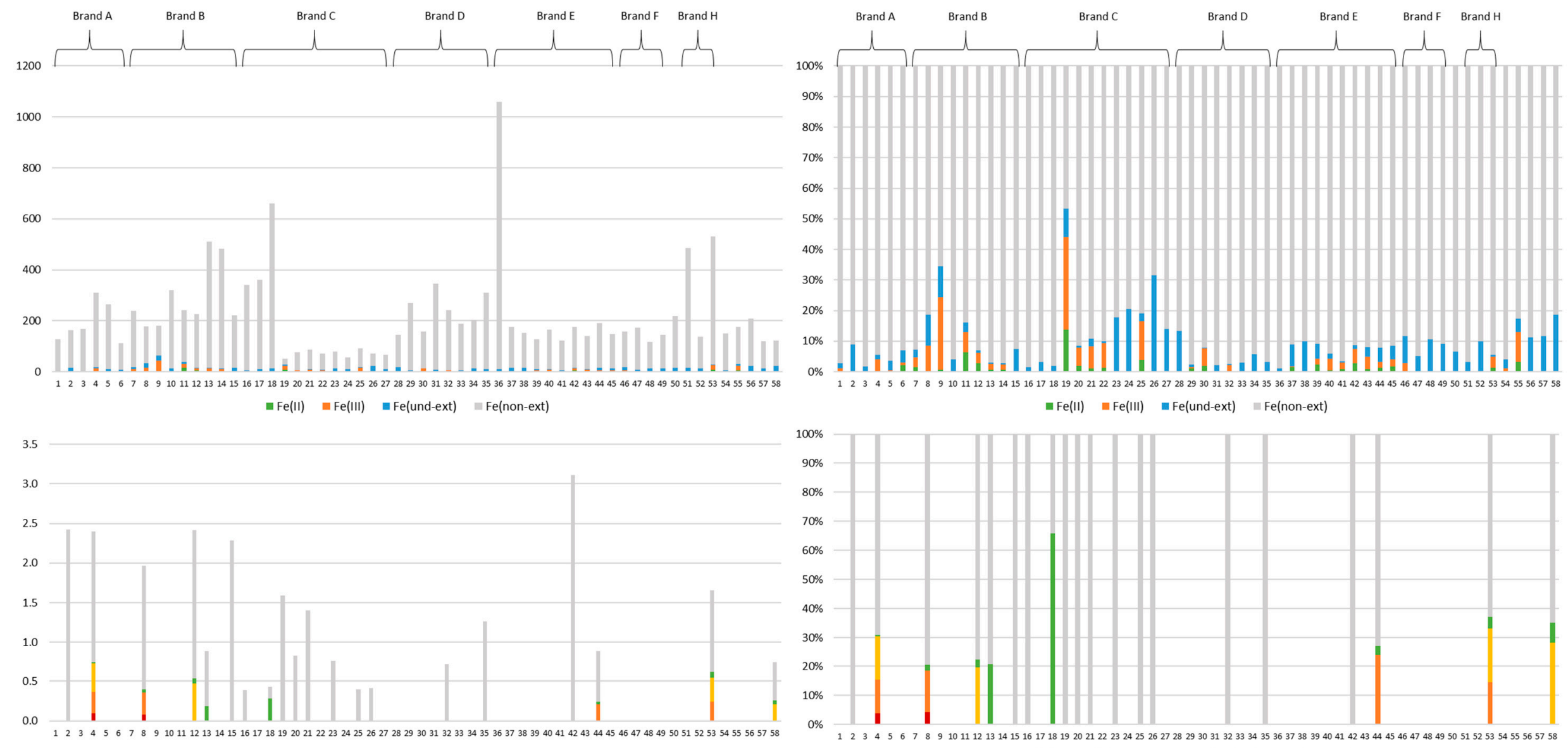

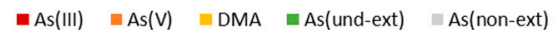

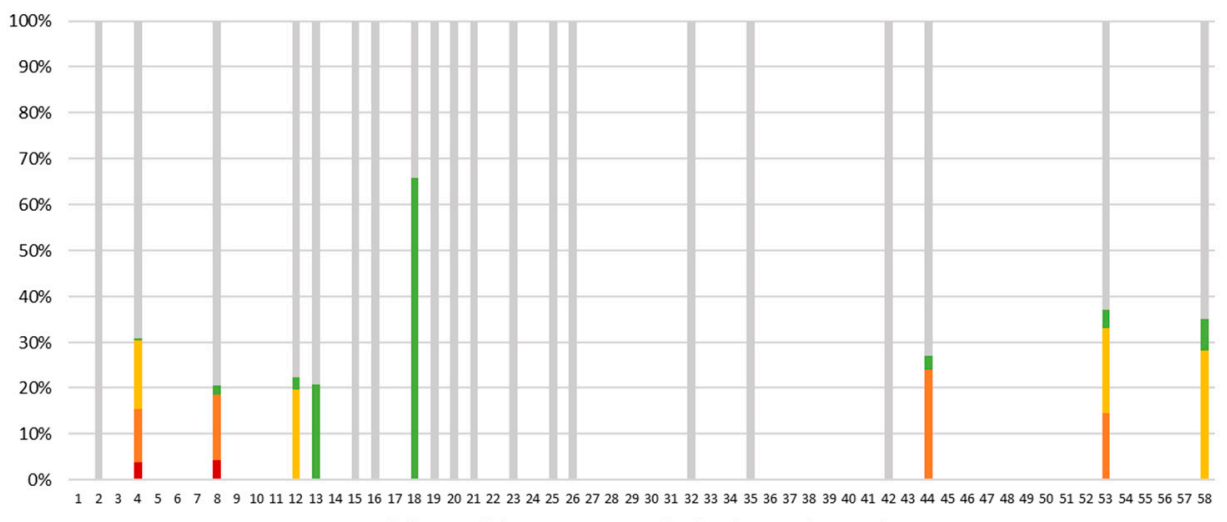

(a)

(b)

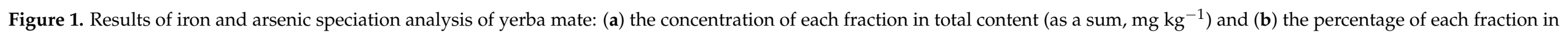

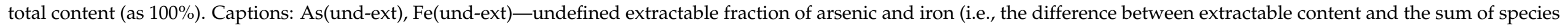
content); As(non-ext), Fe(non-ext)—non-extractable fraction of arsenic or iron (i.e., the difference between total and extractable content). 
The determination of two Fe species has not been performed on yerba mate samples yet, except the introduction as an application material for HPLC-ICP OES and HPLCMIP OES [13] and 2 HPLC-MSIS-ICP OES [17], therefore no comparable data are found in the literature. In the first work, higher content of $\mathrm{Fe}(\mathrm{II})$ and $\mathrm{Fe}(\mathrm{III})$ were found in 2 (15-31 $\mathrm{mg} \mathrm{kg}^{-1}$ ) and three samples (16-43 $\mathrm{mg} \mathrm{kg}^{-1}$ ) respectively [13]. In the second study, $\mathrm{Fe}(\mathrm{III})$ was found in the range from 1.33 to $19.1 \mathrm{mg} \mathrm{kg}^{-1}$ in all samples $(n=8)$, while Fe(II) was determined in four samples (3.07-7.05 $\mathrm{mg} \mathrm{kg}^{-1}$ ) [17]. The dominance of Fe(III) was observed in mentioned studies what may indicate the implication of the oxidizing conditions of the production process of yerba mate (e.g., roasting) [24]. Based on data from preliminary studies [13,17], it was expected that the content of ionic Fe(II) and Fe(III) in yerba mate is widespread. Surprisingly, only Fe(und-ext) was detected in 27 samples. On the one hand, this may indicate the presence of certain extractable iron complex compounds in yerba mate, which remain stable despite the use of ultrasound-assisted extraction and are inert towards cation-exchange column. On the other hand, these complexes could also be formed with any compounds extractable under these conditions from the sample matrix. Nevertheless, in order to confirm or reject this hypothesis, it would be advisable to continue speciation studies on yerba mate, including by increasing the number of samples as well as analytes.

\subsection{Total and Extractable Content of Selected Elements}

The samples were considered as a whole $(n=58)$ and three groups, depending on the country of origin (Argentina, Brazil or Paraguay), kind (con palo or despalada) or composition (pure yerba mate or those with additives) (Table 1). The total content of selected essential trace and potentially toxic elements in yerba mate (Ilex paraguariensis) was presented in Table 4. The Kolmogorov-Smirnov, Lilliefors and Shapiro-Wilk tests indicated that the data did not follow a normal distribution (except $\mathrm{Cu}$, what may be related with using $\mathrm{Cu}$ containing chemical products to control fungal diseases). According to this, the Spearman's rank correlation coefficient was used and results are discussed in Section 3.3.

Nine elements ( $\mathrm{Al}, \mathrm{Cd}, \mathrm{Co}, \mathrm{Cr}, \mathrm{Cu}, \mathrm{Fe}, \mathrm{Mn}, \mathrm{Ni}$ and $\mathrm{Zn}$ ) were found $\mathrm{AQL}$ in all samples. Among the trace elements in yerba mate, the manganese content is indisputably the highest. Generally, the following order of total concentration (as median): $\mathrm{Mn}>\mathrm{Al}>\mathrm{Fe}>\mathrm{Zn}>$ $\mathrm{Cu}>\mathrm{Ni}>$ other elements, was observed in the whole population and every group which was reported before in several studies $[11,20,22,23]$. The only difference was $\mathrm{Fe}>\mathrm{Al}$ in Paraguayan samples (Table 4). Other elements, which were found in the whole population $(n=58)$, were arranged in the following order: $\mathrm{Cr}>\mathrm{Co}>\mathrm{Cd}$. Moreover, the same order was also observed for despalada, yerba mate with additives or those originating from Brazil and Paraguay. However, the different order $(\mathrm{Cr}>\mathrm{Cd}>\mathrm{Co})$ was found in con palo and pure yerba mate. The order $\mathrm{Cr}>\mathrm{Cd}>\mathrm{Co}$ was also reported in the literature $[11,20]$. The order $\mathrm{Co}>\mathrm{Cr}>\mathrm{Cd}$ was observed in the case of Argentinian samples $(n=15)$. Seven elements, As, $\mathrm{Hg}$, Li, Mo, Pb, Sb and Se, were found AQL in 20, 27, 42, 54, 15, 50 and 38 samples respectively (Table 5). The order $\mathrm{As}>\mathrm{Sb}>\mathrm{Se}>\mathrm{Pb}$ was observed in the whole population and con palo samples. Moreover, the order $\mathrm{Sb}>\mathrm{Se}>\mathrm{As}>\mathrm{Pb}$ was found in the case of despalada and Brazilian samples while it was different for Argentinian (As $>\mathrm{Sb}>$ $\mathrm{Se}>\mathrm{Pb})$, Paraguayan $(\mathrm{Sb}>\mathrm{As}>\mathrm{Se}>\mathrm{Pb})$ samples and pure yerba mate $(\mathrm{As}>\mathrm{Pb}>\mathrm{Sb}>$ $\mathrm{Se})$. Moreover, $\mathrm{Pb}>$ Se distinguished pure and Brazilian samples. The content of $\mathrm{Hg}, \mathrm{Li}$ and Mo was similarly low and the order $\mathrm{Hg}>\mathrm{Mo}>\mathrm{Li}$ was observed in each subgroup and the whole population. It is worth mentioning that the same order, containing all of 16 elements (in total content), was observed in two subgroups (despalada and Brazilian samples). The above compliance is due to the fact that all Brazilian samples $(n=23)$ are despalada $(n=26)$. 


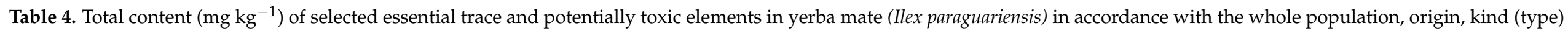
and composition (purity).

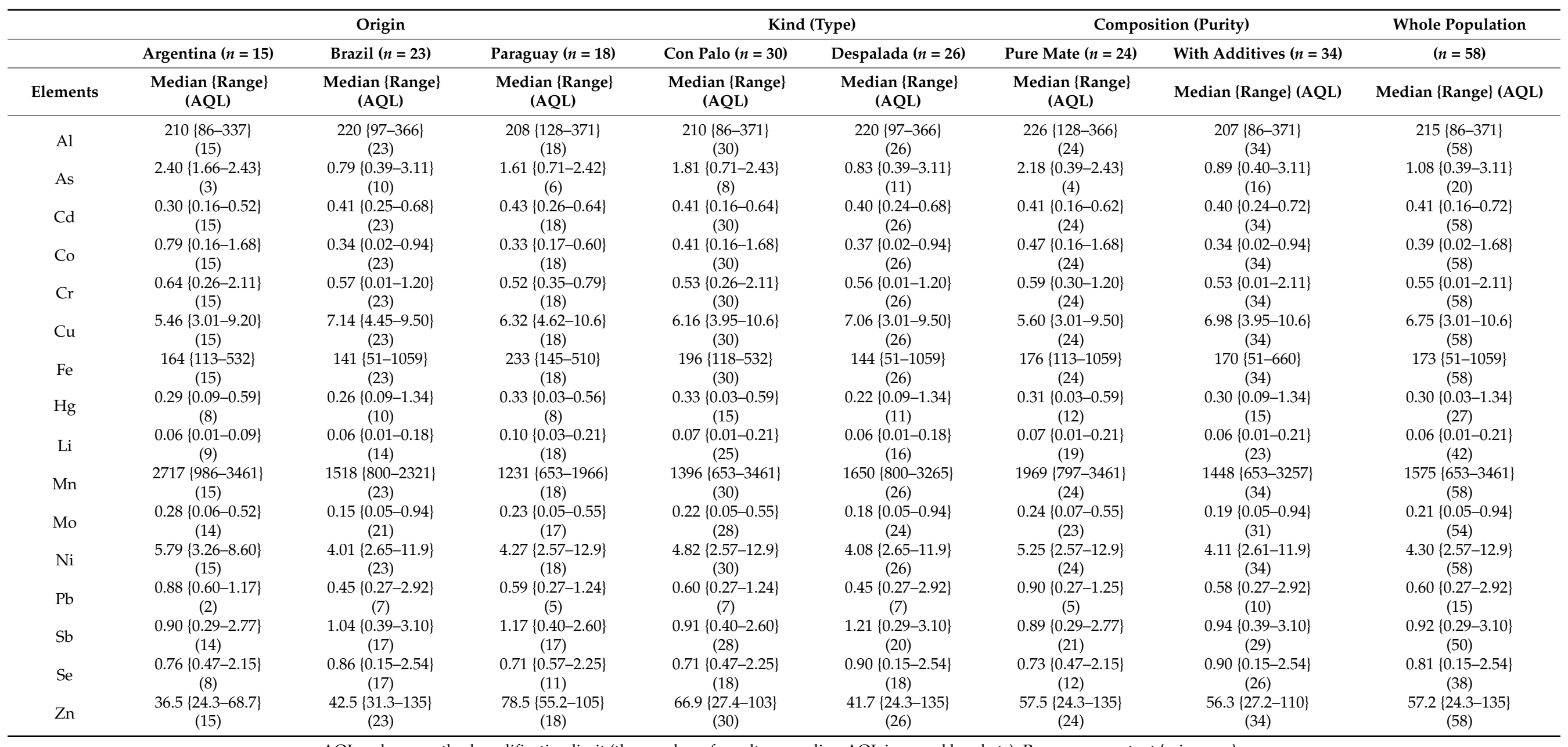

AQL-above method qualification limit (the number of results exceeding AQL in round brackets); Range—as content \{min-max\}. 


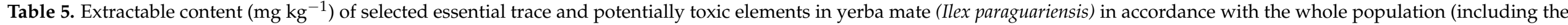
percentage of extraction), origin, kind (type) and composition (purity).

\begin{tabular}{|c|c|c|c|c|c|c|c|c|c|}
\hline & \multicolumn{3}{|c|}{ Origin } & \multicolumn{2}{|c|}{ Kind (Type) } & \multicolumn{2}{|c|}{ Composition (Purity) } & \multicolumn{2}{|c|}{ Whole Population $(n=58)$} \\
\hline & Argentina $(n=15)$ & Brazil $(n=23)$ & Paraguay $(n=18)$ & Con Palo $(n=30)$ & Despalada $(n=26)$ & Pure Mate $(n=24)$ & With Additives $(n=34)$ & Content $\left(\mathrm{mg} \mathrm{kg}^{-1}\right)$ & $\%$ of Total Content \\
\hline Elements & $\begin{array}{l}\text { Median \{Range }\} \\
\text { (AQL) }\end{array}$ & $\begin{array}{c}\text { Median }\{\text { Range }\} \\
\text { (AQL) }\end{array}$ & $\begin{array}{c}\text { Median }\{\text { Range }\} \\
\text { (AQL) }\end{array}$ & $\begin{array}{c}\text { Median \{Range }\} \\
\text { (AQL) }\end{array}$ & $\begin{array}{l}\text { Median \{Range }\} \\
\text { (AQL) }\end{array}$ & $\begin{array}{l}\text { Median \{Range }\} \\
\text { (AQL) }\end{array}$ & Median \{Range\} (AQL) & $\begin{array}{l}\text { Median \{Range }\} \\
\text { (AQL) }\end{array}$ & $\begin{array}{c}\text { Median }\{\text { Range }\} \\
\text { (AQL) }\end{array}$ \\
\hline $\mathrm{Al}$ & $\begin{array}{c}66.2\{8.70-132\} \\
(15)\end{array}$ & $\begin{array}{c}51.1\{16.3-124\} \\
(23)\end{array}$ & $\begin{array}{c}41.6 \underset{(12.5-131\}}{(18)} \\
\text { (1) }\end{array}$ & $\begin{array}{c}47.6\{8.70-132\} \\
(30)\end{array}$ & $\begin{array}{c}54.4\{16.3-124\} \\
(26)\end{array}$ & $\begin{array}{c}60.1\{8.70-132\} \\
(24)\end{array}$ & $\begin{array}{c}49.2\{20.2-131\} \\
(34)\end{array}$ & $\begin{array}{c}52.9\{8.70-132\} \\
(58)\end{array}$ & $\begin{array}{c}28\{4-80\} \\
(58)\end{array}$ \\
\hline As & $\begin{array}{c}0.68\{0.62-0.74\} \\
(2)\end{array}$ & $\begin{array}{c}0.26\{0.24-0.28\} \\
(2)\end{array}$ & $\begin{array}{c}0.40\{0.18-0.54\} \\
\text { (3) }\end{array}$ & $\begin{array}{c}0.47\{0.18-0.62\} \\
(4)\end{array}$ & $\begin{array}{c}0.28\left\{\begin{array}{l}\{0.24-0.74\} \\
(3)\end{array}\right.\end{array}$ & $\begin{array}{c}0.57\{0.40-0.74\} \\
(2)\end{array}$ & $\begin{array}{c}0.27\{0.18-0.62\} \\
(6)\end{array}$ & $\begin{array}{c}0.34\{0.18-0.74\} \\
(8)\end{array}$ & $\begin{array}{c}29\{20-66\} \\
(8)\end{array}$ \\
\hline $\mathrm{Cd}$ & $\begin{array}{c}0.05\{0.02-0.22\} \\
(13)\end{array}$ & $\begin{array}{c}0.06\{0.02-0.21\} \\
(20)\end{array}$ & $\begin{array}{c}0.11\{0.04-0.35\} \\
(13)\end{array}$ & $\begin{array}{c}0.07\{0.02-0.35\} \\
(23)\end{array}$ & $\begin{array}{c}0.06\{0.02-0.21\} \\
(23)\end{array}$ & $\begin{array}{c}0.05\{0.02-0.35\} \\
(21)\end{array}$ & $\begin{array}{c}0.08\{0.02-0.33\} \\
(27)\end{array}$ & $\begin{array}{c}0.07\{0.02-0.35\} \\
(48)\end{array}$ & $\begin{array}{c}17\{3-86\} \\
(48)\end{array}$ \\
\hline Co & $\begin{array}{c}0.24\{0.07-0.51\} \\
(14)\end{array}$ & $\begin{array}{c}0.18\{0.03-0.60\} \\
(17)\end{array}$ & $\begin{array}{c}0.16\{0.02-0.44\} \\
(15)\end{array}$ & $\begin{array}{c}0.18\{0.03-0.51\} \\
(26)\end{array}$ & $\begin{array}{c}0.17\{0.02-0.60\} \\
(20)\end{array}$ & $\begin{array}{c}0.16\{0.02-0.51\} \\
(22)\end{array}$ & $\begin{array}{c}0.19\{0.03-0.60\} \\
(25)\end{array}$ & $\begin{array}{c}0.18\{0.02-0.60\} \\
(47)\end{array}$ & $\begin{array}{c}37\{3-99.8\} \\
(47)\end{array}$ \\
\hline $\mathrm{Cr}$ & $\begin{array}{c}x \\
x\end{array}$ & $\begin{array}{c}x \\
254077401\end{array}$ & $\begin{array}{c}x \\
10506101\end{array}$ & 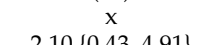 & $\begin{array}{c}x \\
265077\end{array}$ & 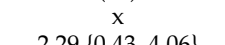 & $\begin{array}{c}x \\
250106 \\
0.5701\end{array}$ & $\begin{array}{c}x \\
x\end{array}$ & $\begin{array}{c}x \\
390 \\
309\end{array}$ \\
\hline $\mathrm{Cu}$ & $\begin{array}{c}2.22\left\{\begin{array}{c}\{0.43-4.52\} \\
(15)\end{array}\right. \\
\text {. }\end{array}$ & 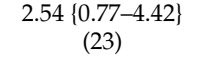 & $\begin{array}{c}1.95\{0.56-4.91\} \\
(18)\end{array}$ & 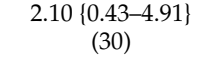 & $\begin{array}{c}2.65\left\{\begin{array}{c}\{0.77-4.42\} \\
(26)\end{array}\right. \\
\text { (1) }\end{array}$ & $\begin{array}{c}2.29 \\
\underset{(24)}{\{0.43-4.06\}}\end{array}$ & $\begin{array}{c}2.50\left\{\begin{array}{c}\{0.86-5.79\} \\
(34)\end{array}\right. \\
\text { (a) }\end{array}$ & $\begin{array}{c}2.30\{0.43-5.79\} \\
(58)\end{array}$ & $\begin{array}{c}39\{8-99\} \\
(58)\end{array}$ \\
\hline $\mathrm{Fe}$ & $\begin{array}{c}13.8\{2.92-29.4\} \\
(15)\end{array}$ & $\begin{array}{c}11.5\{4.18-27.3\} \\
(23)\end{array}$ & $\begin{array}{c}13.4\{5.72-62.8\} \\
(18)\end{array}$ & $\begin{array}{c}13.8\{2.92-62.8\} \\
(30)\end{array}$ & $\begin{array}{c}11.9\left\{\begin{array}{c}\{4.18-27.3\} \\
(26)\end{array}\right.\end{array}$ & $\begin{array}{c}12.9\{2.92-33.3\} \\
(24)\end{array}$ & $\begin{array}{c}13.8\{4.18-62.8\} \\
(34)\end{array}$ & $\begin{array}{c}13.2\{2.92-62.8\} \\
(58)\end{array}$ & $\begin{array}{c}8\{1-53\} \\
(58)\end{array}$ \\
\hline $\mathrm{Hg}$ & $\begin{array}{c}0.08^{*} \\
(1)\end{array}$ & BQL & BQL & $\begin{array}{c}0.08^{*} \\
(1)\end{array}$ & BQL & BQL & $\begin{array}{c}0.08^{*} \\
(1)\end{array}$ & $\begin{array}{c}0.08^{*} \\
(1)\end{array}$ & $\begin{array}{l}84^{*} \\
(1)\end{array}$ \\
\hline $\mathrm{Li}$ & $\mathrm{BQL}$ & $\mathrm{BQL}$ & $\begin{array}{c}0.03\{0.01-0.04\} \\
(2)\end{array}$ & $\begin{array}{c}0.03\{0.01-0.04\} \\
(2)\end{array}$ & $\mathrm{BQL}$ & BQL & $\begin{array}{c}0.03\{0.01-0.04\} \\
(2)\end{array}$ & $\begin{array}{c}0.03\{0.01-0.04\} \\
(2)\end{array}$ & $\begin{array}{c}34\{33-35\} \\
(2)\end{array}$ \\
\hline $\mathrm{Mn}$ & $\begin{array}{c}513\{58.7-1110\} \\
(15)\end{array}$ & $\begin{array}{c}326\{126-860\} \\
(23)\end{array}$ & $\begin{array}{c}239\{29.3-913\} \\
(18)\end{array}$ & $\begin{array}{c}317\{29.3-1110\} \\
(30)\end{array}$ & $\begin{array}{c}342\{126-922\} \\
(26)\end{array}$ & 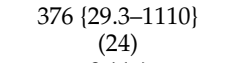 & $\begin{array}{c}313\{63.9-1085\} \\
(34)\end{array}$ & $\begin{array}{c}343\{29.3-1110\} \\
(58)\end{array}$ & $\begin{array}{c}23\{2-66\} \\
(58)\end{array}$ \\
\hline Mo & BQL & $\begin{array}{c}0.14 \\
(1)\end{array}$ & $\begin{array}{c}0.11 * \\
(1)\end{array}$ & $\begin{array}{c}0.11 * \\
(1)\end{array}$ & $\begin{array}{c}0.14 \\
(1)\end{array}$ & $\begin{array}{c}0.11 * \\
(1)\end{array}$ & $\begin{array}{c}0.13\{0.13-0.14\} \\
(2)\end{array}$ & $\begin{array}{c}0.13\{0.11-0.14\} \\
(3)\end{array}$ & $\begin{array}{c}57\{32-60\} \\
(3)\end{array}$ \\
\hline $\mathrm{Pb}$ & $\begin{array}{l}0.82 * \\
(1)\end{array}$ & $\begin{array}{c}0.71\{0.11-1.37\} \\
(3)\end{array}$ & $\begin{array}{c}0.44\{0.21-0.59\} \\
(3)\end{array}$ & $\begin{array}{c}0.51\{0.21-0.82\} \\
(4)\end{array}$ & $\begin{array}{c}0.71\{0.11-1.37\} \\
(3)\end{array}$ & $\begin{array}{c}0.76\{0.71-0.82\} \\
(2)\end{array}$ & $\begin{array}{c}0.44\{0.11-1.37\} \\
(5)\end{array}$ & $\begin{array}{c}0.59\{0.11-1.37\} \\
\text { (7) }\end{array}$ & $\begin{array}{c}56\{17-75\} \\
(7)\end{array}$ \\
\hline $\mathrm{Sb}$ & $\begin{array}{c}0.44\{0.13-0.80\} \\
(13)\end{array}$ & $\begin{array}{c}0.27\{0.09-0.65\} \\
(17)\end{array}$ & $\begin{array}{c}0.39\{0.08-1.17\} \\
(16)\end{array}$ & $\begin{array}{c}0.42\{0.08-1.17\} \\
(27)\end{array}$ & $\begin{array}{c}0.27\{0.09-0.65\} \\
(19)\end{array}$ & $\begin{array}{c}0.34\{0.08-0.68\} \\
(19)\end{array}$ & 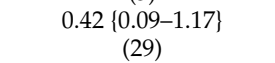 & $\begin{array}{c}0.39\{0.08-1.17\} \\
(48)\end{array}$ & $\begin{array}{c}36\{9-94\} \\
(48)\end{array}$ \\
\hline Se & $\begin{array}{c}0.70\{0.15-1.25\} \\
(2)\end{array}$ & $\begin{array}{c}0.88\{0.83-0.95\} \\
(3)\end{array}$ & $\begin{array}{c}1.12 * \\
(1)\end{array}$ & $\begin{array}{c}0.64\{0.15-1.12\} \\
(2)\end{array}$ & $\begin{array}{c}0.91\{0.83-1.25\} \\
(4)\end{array}$ & $\begin{array}{c}0.70\{0.15-1.25\} \\
(2)\end{array}$ & $\begin{array}{c}0.88\{0.18-1.12\} \\
\text { (5) }\end{array}$ & $\begin{array}{c}0.88\{0.15-1.25\} \\
\text { (7) }\end{array}$ & $\begin{array}{c}61\{19-88\} \\
(7)\end{array}$ \\
\hline $\mathrm{Zn}$ & $\begin{array}{c}16.1\{1.69-36.2\} \\
(15)\end{array}$ & $\begin{array}{c}19.7\{6.79-33.7\} \\
(23)\end{array}$ & $\begin{array}{c}23.9\{5.50-72.2\} \\
(18)\end{array}$ & $\begin{array}{c}19.5\{1.69-72.2\} \\
(30)\end{array}$ & $\begin{array}{c}19.4\{6.79-37.6\} \\
(26)\end{array}$ & $\begin{array}{c}15.4\{1.69-66.3\} \\
(24)\end{array}$ & $\begin{array}{c}21.6\{6.79-72.2\} \\
(34)\end{array}$ & $\begin{array}{c}19.4\{1.69-72.2\} \\
(58)\end{array}$ & $\begin{array}{c}35\{5-99\} \\
(58)\end{array}$ \\
\hline
\end{tabular}

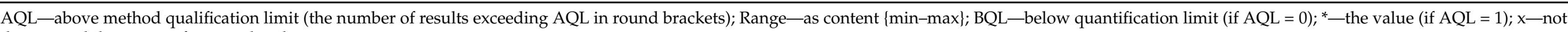
determined due to interference, details in text. 
The extractable content of selected essential trace and potentially toxic elements in 58 samples of yerba mate (Ilex paraguariensis) is presented in Table 5. In contrast to total content, only five elements were found AQL in all samples ( $\mathrm{Al}, \mathrm{Cu}, \mathrm{Fe}, \mathrm{Mn}$, and $\mathrm{Zn}$ ). Moreover, Ni was detected BQL only in one sample (no. 1), which was a pure yerba mate con palo from Argentina. In turn, Cd, Co and Sb were determined in 48, 47 and 48 extracts, respectively. It is worth noting that other studied elements were found AQL only in one $(\mathrm{Hg})$, two $(\mathrm{Li})$, three $(\mathrm{Mo})$, seven $(\mathrm{Pb}$ and $\mathrm{Se})$ and eight samples (As). However, $\mathrm{Cr}$ extractable content was significantly higher than its total content. The increase in the results was repeatable and it seemed to be caused by unexpected signal interferences related to the selection of the sample preparation method (ultrasonic extraction with diluted phosphoric acid) or a peculiarity of the sample matrix. Nevertheless, this problem would require further clarification, therefore the results for the Cr extractable content was rejected.

The following order of extractable content was observed (as median) in the whole population and each subgroup: $\mathrm{Mn}>\mathrm{Al}>\mathrm{Zn}>\mathrm{Fe}>\mathrm{Cu}>\mathrm{Ni}>$ other elements. Considering only elements, whose results were BQL for $<20 \%$ of all samples (i.e., $\mathrm{Al}, \mathrm{Cd}, \mathrm{Co}, \mathrm{Cu}, \mathrm{Fe}, \mathrm{Mn}$, $\mathrm{Sb}$, and $\mathrm{Zn}$ ), the order for each subgroup as well as the whole population was identical: $\mathrm{Mn}>\mathrm{Al}>\mathrm{Zn}>\mathrm{Fe}>\mathrm{Cu}>\mathrm{Ni}>\mathrm{Sb}>\mathrm{Co}>\mathrm{Cd}$. In the case of other elements (As, $\mathrm{Pb}$ and Se), the order $\mathrm{Se}>\mathrm{Pb}>$ As was found in the whole population and four subgroups (con palo, despalada, yerba mate with additives and those originating from Brazil). The order $\mathrm{Pb}>\mathrm{Se}$ $>$ As was observed for pure yerba mate $(n=24)$.

For the whole sample population $(n=58)$, the percentages of extraction (as median) were arranged in the ascending order: Fe (8\%), Cd (17\%), Mn (23\%), Ni (27\%), Al (28\%), As (29\%), Li (34\%), Zn (35\%), Sb (36\%), Co (37\%), Cu (39\%), Pb (56\%), Mo (57\%), Se (61\%), and $\mathrm{Hg}(84 \%)$, however $\mathrm{Hg}(\mathrm{ext})$ was only determined AQL in one sample (no. 53, Argentinian yerba mate con palo with additives). Comparing to other studies, where the percentages were obtained after hot water extraction $[10,20,22,23,25]$, the percentages in this study were both lower ( $\mathrm{Co})$ and higher ( $\mathrm{Al}$ and $\mathrm{Se}$ ). In the case of other elements, it is difficult to clearly indicate whether the ultrasound-assisted extraction in $1 \mathrm{~mol} \mathrm{~L}{ }^{-1} \mathrm{H}_{3} \mathrm{PO}_{4}$ (at room temperature) allows to extract its higher content than a traditional extraction in hot water $\left(80 \pm 10^{\circ} \mathrm{C}\right)$. According to the studies mentioned above, $\mathrm{As}, \mathrm{Cu}, \mathrm{Li}, \mathrm{Mn}$ and $\mathrm{Ni}$ were usually better extracted using hot water and $\mathrm{Cd}, \mathrm{Fe}, \mathrm{Mo}, \mathrm{Pb}$ and $\mathrm{Zn}$ were rather better extracted with diluted phosphoric acid [10,20,22,23,25].

In the case of tea or yerba mate, the maximum limits of total concentrations of As, $\mathrm{Cd}$ and $\mathrm{Pb}$ were established by legislation $\left(0.6,0.4\right.$, and $0.6 \mathrm{mg} \mathrm{kg}^{-1}$, respectively) [21], however, the results for arsenic have already been discussed in Section 3.1. The content of $\mathrm{Pb}$ (total) and $\mathrm{Pb}($ ext $)$ exceeded the recommended limit $\left(0.6 \mathrm{mg} \mathrm{kg}^{-1}\right)$ in eight and three samples (nos. 16, 19 and 50), respectively. The mean value of $\mathrm{Pb}$ (total) $\left(0.86 \mathrm{mg} \mathrm{kg}^{-1}\right)$ was slight higher than in the literature $[10,20,22,23]$, however samples exceeding the $\mathrm{Pb}$ limit were also reported before $[1,15,19,26]$. Nevertheless, $\mathrm{Pb}$ (total) was found BQL in 43 samples. In turn, Cd(total) was determined in all samples $(n=58)$, while Cd(ext) was found AQL in 48 samples. The content of $\mathrm{Cd}$ (total) and $\mathrm{Cd}(\mathrm{ext})$ exceeded the recommended limit $\left(0.4 \mathrm{mg} \mathrm{kg}^{-1}\right)$ in 30 and six samples (nos. 4, 8, 43, 46, 50, 53), respectively. Moreover, the mean value of $\mathrm{Cd}$ (total) (also the median, $0.41 \mathrm{mg} \mathrm{kg}^{-1}$ ) exceeded the limit. These results corresponds to several studies which indicate that $\mathrm{Cd}$ was frequently found above $0.4 \mathrm{mg} \mathrm{kg}^{-1}[1,15,19,20,22,23,26,27]$. Based on these findings, these concentrations may be considered natural and established limits should be revised, especially for $\mathrm{Cd}$ and $\mathrm{Pb}[26,27]$.

For easier evaluation of the results obtained in this study, the total content of elements in yerba mate samples was compared with the literature data (Table 6). In addition, the results were also divided into groups (origin, kind and composition), as pure yerba mate samples and those with additives have not been compared previously in terms of the elemental composition. 
Table 6. Total content (as mean $\pm \mathrm{SD}, \mathrm{mg} \mathrm{kg}^{-1}$ ) obtained in this study in comparison to the literature data.

\begin{tabular}{|c|c|c|c|c|c|c|c|c|c|c|c|c|c|c|c|c|c|c|c|}
\hline \multicolumn{2}{|c|}{ Group } & $\mathrm{N}$ & $\mathrm{Al}$ & As & $\mathrm{Cd}$ & Co & $\mathrm{Cr}$ & $\mathrm{Cu}$ & $\mathrm{Fe}$ & $\mathrm{Hg}$ & $\mathrm{Li}$ & $\mathrm{Mn}$ & Mo & $\mathrm{Ni}$ & $\mathrm{Pb}$ & $\mathrm{sb}$ & Se & $\mathrm{Zn}$ & Ref. \\
\hline \multirow{2}{*}{\multicolumn{2}{|c|}{ Whole population }} & $\begin{array}{l}58 \\
54\end{array}$ & $\begin{array}{r}217 \pm 67 \\
361 \pm 108\end{array}$ & $\begin{array}{c}1.35 \pm 0.81 \\
0.052 \pm 0.251\end{array}$ & $\begin{array}{c}0.41 \pm 0.13 \\
0.410 \pm 0.180\end{array}$ & $\begin{array}{c}0.49 \pm 0.37 \\
0.169 \pm 0.956\end{array}$ & $\begin{array}{c}0.60 \pm 0.28 \\
0.528 \pm 0.240\end{array}$ & $\begin{array}{l}6.69 \pm 1.60 \\
11.9 \pm 2.06\end{array}$ & $\begin{array}{l}221 \pm 168 \\
205 \pm 89.1\end{array}$ & $\begin{array}{c}0.33 \pm 0.26 \\
\mathrm{ND}\end{array}$ & $\begin{array}{c}0.08 \pm 0.05 \\
0.085 \pm 0.079\end{array}$ & $\begin{array}{l}1727 \pm 735 \\
1078 \pm 377\end{array}$ & $\begin{array}{c}0.26 \pm 0.18 \\
0.066 \pm 0.325\end{array}$ & $\begin{array}{l}4.79 \pm 2.00 \\
2.74 \pm 0.945\end{array}$ & $\begin{array}{c}0.86 \pm 0.65 \\
0.314 \pm 0.181\end{array}$ & $\begin{array}{c}1.18 \pm 0.68 \\
\mathrm{ND}\end{array}$ & $\begin{array}{l}0.93 \pm 0.52 \\
\mathrm{ND}\end{array}$ & $\begin{array}{l}59.4 \pm 24.9 \\
63.6 \pm 25.0\end{array}$ & $\begin{array}{l}\text { This study } \\
\text { [11] }\end{array}$ \\
\hline & & $\begin{array}{l}54 \\
32\end{array}$ & $\begin{array}{l}301 \pm 108 \\
90.4 \pm 50.9\end{array}$ & & $\begin{array}{c}0.411 \pm \pm 0.180 \\
0.19 \pm 0.12\end{array}$ & $\begin{array}{c}0.169 \pm 0.0566 \\
B Q L\end{array}$ & $\begin{array}{c}.058 \pm 0.240 \\
0.35 \pm 0.13\end{array}$ & $\begin{array}{l}11.9 \pm 2.06 \\
5.17 \pm 2.07\end{array}$ & $\begin{array}{l}21.6 \pm 16.1 \\
21.5\end{array}$ & $\mathrm{ND}$ & $\begin{array}{l}.0 .03 \pm 0.079 \\
3.57 \pm 1.94\end{array}$ & $\begin{array}{l}66.4 \pm 30.2 \\
60.27\end{array}$ & $\begin{array}{c}0.060 \pm \pm 0.425 \\
0.60 \pm 0.40\end{array}$ & $\begin{array}{l}2.7 .4 \pm 0.945 \\
1.39 \pm 0.44\end{array}$ & $\begin{array}{r}0.314 \pm 0.181 \\
0.36 \pm 0.41\end{array}$ & $\mathrm{ND}$ & $\mathrm{ND}$ & $\begin{array}{l}56.3 . \pm \pm 25.0 \\
32.5 \pm 11.9\end{array}$ & ${ }_{[23]}^{[11]}$ \\
\hline \multirow{5}{*}{ Origin } & & 15 & $214 \pm 63$ & $2.16 \pm 0.36$ & $0.32 \pm 0.13$ & $0.88 \pm 0.43$ & $0.73 \pm 0.40$ & $5.73 \pm 1.57$ & $216 \pm 127$ & $0.27 \pm 0.16$ & $0.05 \pm 0.03$ & $2543 \pm 672$ & $0.28 \pm 0.14$ & $5.71 \pm 1.41$ & $0.88^{\mathrm{b}}$ & $1.07 \pm 0.60$ & $0.89 \pm 0.49$ & $43.1 \pm 15.4$ & This study \\
\hline & Argentina & $\begin{array}{l}14 \\
10\end{array}$ & $\begin{array}{c}347 \pm 60 \\
\mathrm{ND}\end{array}$ & $\begin{array}{c}0.04 \pm 0.01 \\
\mathrm{ND}\end{array}$ & $\begin{array}{c}0.373 \pm 0.167 \\
0.31^{a}\end{array}$ & $\underset{\mathrm{ND}}{0.209 \pm 0.073}$ & $\begin{array}{c}0.689 \pm 0.18 \\
1.1 .5 \mathrm{a}\end{array}$ & $\begin{array}{r}12.6 \pm 2.0 \\
7.722^{a}\end{array}$ & $\begin{array}{l}196 \pm 42 \\
200 \mathrm{a}^{\mathrm{a}}\end{array}$ & $\begin{array}{l}\mathrm{ND} \\
\mathrm{ND}\end{array}$ & 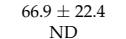 & $\begin{array}{r}1368 \pm 256 \\
1730^{a}\end{array}$ & 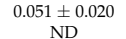 & $\begin{array}{l}2.72 \pm 0.718 \\
3.96^{\mathrm{a}}\end{array}$ & $\begin{array}{r}0.222 \pm 0.107 \\
0.40^{a}\end{array}$ & $\begin{array}{l}\text { BDL } \\
\text { ND }\end{array}$ & $\begin{array}{l}\text { BDD } \\
\text { ND }\end{array}$ & $\begin{array}{l}79.4 \pm 17.7 \\
78.01 \mathrm{a}\end{array}$ & {$[20]$} \\
\hline & Brazil & 19 & $\begin{array}{l}291156 \\
2911\end{array}$ & $\begin{array}{l}0.05 \pm 0.03 \\
0.0400\end{array}$ & $0.491 \pm 0.225$ & $\begin{array}{l}0.121 \pm 0.094 \\
0.1209 \pm 0\end{array}$ & $0.37 \pm 0.19$ & $\begin{array}{l}11.4 \pm 2.1 \\
0.200\end{array}$ & $\begin{array}{l}154 \pm 48 \\
150 \pm 01\end{array}$ & $\mathrm{ND}$ & $\begin{array}{l}74.5 \pm 134 \\
0.11 \pm 0.134\end{array}$ & $\begin{array}{l}987 \pm 352 \\
98125\end{array}$ & $\begin{array}{l}0.066=0.040 \\
0.0050\end{array}$ & $\begin{array}{l}2.38 \pm 1.14 \\
.10\end{array}$ & $\begin{array}{l}0.407 \pm 0.230 \\
0.02 \pm 0.20\end{array}$ & $\begin{array}{l}\text { BDL } \\
\text { BD }\end{array}$ & BDL & $\begin{array}{l}40.2 \pm 14.7 \\
54513\end{array}$ & 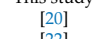 \\
\hline & & 18 & $\begin{array}{l}219 \pm 63 \\
219\end{array}$ & $\begin{array}{l}0.04 \pm 0.02 \\
1.59 \pm 0.67\end{array}$ & $\begin{array}{l}0.40 \pm \pm .13 \\
0.45 \pm 0.10\end{array}$ & $0.33 \pm 0.11$ & $0.52 \pm 0.11$ & $\begin{array}{l}.92 \pm 0.93 \\
6.44 \pm 1.62\end{array}$ & $\begin{array}{l}250 \pm \pm 102 \\
257 \pm 121\end{array}$ & $0.34 \pm 0.16$ & $\begin{array}{l}0.11 \pm 0.00 \\
0.10 \pm 0.05\end{array}$ & $\begin{array}{l}1513 \pm 532 \\
1224 \pm 339\end{array}$ & $\begin{array}{l}0.05 \pm 0.005 \\
0.28 \pm 0.17\end{array}$ & $\begin{array}{l}2.19 \pm 0.055 \\
4.53 \pm 2.25\end{array}$ & $\begin{array}{l}0.28 \pm 0.122 \\
0.78 \pm 0.38\end{array}$ & $1.23 \pm 0.62$ & $\begin{array}{l}.03 \pm 0.02 \\
0.97 \pm 0.55\end{array}$ & $\begin{array}{c}5513 \\
79.0 \pm 12.7\end{array}$ & $\begin{array}{l}\text { This study } \\
\text { Th }\end{array}$ \\
\hline & Paraguay & $\begin{array}{l}14 \\
5\end{array}$ & $\begin{array}{c}384 \pm 62 \\
\mathrm{ND}\end{array}$ & $\begin{array}{l}0.06 \pm 0.03 \\
\mathrm{ND}\end{array}$ & $\begin{array}{r}0.295 \pm 0.082 \\
0.30 \mathrm{a}\end{array}$ & $\begin{array}{c}0.101 \pm 0.084 \\
\mathrm{ND}\end{array}$ & $\begin{array}{c}0.70 \pm 0.13 \\
0.88 \mathrm{a}\end{array}$ & $\begin{array}{c}11.1 \pm 1.9 \\
7.28^{\mathrm{a}}\end{array}$ & $\begin{array}{c}226 \pm 122 \\
1300^{a}\end{array}$ & $\begin{array}{l}\mathrm{ND} \\
\mathrm{ND}\end{array}$ & $\begin{array}{c}59.1 \pm 33.3 \\
\mathrm{ND}\end{array}$ & $\begin{array}{c}730 \pm 150 \\
6800^{\mathrm{a}}\end{array}$ & $\begin{array}{c}0.089 \pm 0.022 \\
\text { ND }\end{array}$ & $\begin{array}{l}2.81 \pm 0.720 \\
3.033^{\mathrm{a}}\end{array}$ & $\begin{array}{c}0.314 \pm 0.178 \\
0.45\end{array}$ & $\begin{array}{l}\text { BDL } \\
\text { ND }\end{array}$ & $\begin{array}{l}\text { BDL } \\
\text { ND }\end{array}$ & $\begin{array}{l}77.3 \pm 25.4 \\
115.05^{\mathrm{a}}\end{array}$ & $\begin{array}{l}{[20]} \\
{[25]}\end{array}$ \\
\hline \multirow[b]{2}{*}{ Kind (type) } & con palo & 30 & $\begin{array}{l}216 \pm 63 \\
203\end{array}$ & $1.70 \pm 0.64$ & $\begin{array}{l}0.4000 .13 \\
0.23\end{array}$ & 0.5600 .42 & $\begin{array}{l}0.600 .31 \\
0.62 \pm 0.31\end{array}$ & $\begin{array}{l}6.2601 .61 \\
6.201\end{array}$ & $\begin{array}{l}237= \pm 118 \\
2375 \mathrm{a}\end{array}$ & $0.32 \pm 0.16$ & $0.08 \pm 0.06$ & $\begin{array}{c}680 \\
1776 \pm 836 \\
1070 a\end{array}$ & $0.26 \pm 0.15$ & $\begin{array}{l}3.03 \pm 2.06 \\
5.06 \pm 2.06\end{array}$ & $\begin{array}{l}0.81 \pm 0.36 \\
0.0\end{array}$ & $1.09 \pm 0.50$ & $\begin{array}{c}0.87 \pm 0.46 \\
0 .\end{array}$ & $\begin{array}{l}115.0 .00 \\
63.7 \pm 20.3 \\
0.960^{a}\end{array}$ & $\begin{array}{l}\text { This study } \\
\text { Tht }\end{array}$ \\
\hline & depnod & $\begin{array}{l}10 \\
26\end{array}$ & $\begin{array}{c}\mathrm{ND} \\
217 \pm 72\end{array}$ & $\begin{array}{l}\mathrm{ND} \\
1.15 \pm 0.86\end{array}$ & $\begin{array}{c}0.33^{\mathrm{d}} \\
0.43 \pm 0.12\end{array}$ & $\begin{array}{c}\mathrm{ND} \\
0.43 \pm 0.29\end{array}$ & $\begin{array}{c}0.95^{\mathrm{a}} \\
0.61 \pm 0.23\end{array}$ & $\begin{array}{c}7.35^{\mathrm{a}} \\
7.07 \pm 1.49\end{array}$ & $\begin{array}{c}150^{\mathrm{a}} \\
208 \pm 215\end{array}$ & $\begin{array}{l}\mathrm{ND} \\
0.35 \pm 0.36\end{array}$ & $\begin{array}{c}\mathrm{ND} \\
0.06 \pm 0.03\end{array}$ & $\begin{array}{c}1170^{\mathrm{a}} \\
1615 \pm 1\end{array}$ & $\begin{array}{c}\mathrm{ND} \\
0.25 \pm 0.22\end{array}$ & $\begin{array}{c}3.27 \mathrm{a} \\
4.47 \pm 1.93\end{array}$ & $\begin{array}{c}0.39 \mathrm{a} \\
0.92 \pm 0.88\end{array}$ & $\begin{array}{l}\mathrm{ND} \\
1.36 \pm 0.85\end{array}$ & $\begin{array}{l}\mathrm{ND} \\
0.97 \pm 0.60\end{array}$ & $\begin{array}{l}99.49^{\mathrm{d}} \\
55.5 \pm 28.7\end{array}$ & 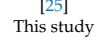 \\
\hline $\begin{array}{c}\text { Composition } \\
\text { (purity) }\end{array}$ & $\begin{array}{l}\text { with } \\
\text { additives }\end{array}$ & 34 & $205 \pm 62$ & $1.24 \pm 0.77$ & $0.43 \pm 0.13$ & $0.38 \pm 0.26$ & $0.59 \pm 0.33$ & $7.06 \pm 1.50$ & $201 \pm 146$ & $0.37 \pm 0.32$ & $0.08 \pm 0.05$ & $1509 \pm 558$ & $0.24 \pm 0.20$ & $4.37 \pm 1.74$ & $0.88 \pm 0.76$ & $1.24 \pm 0.71$ & $0.97 \pm 0.56$ & $60.3 \pm 22.9$ & This study \\
\hline
\end{tabular}

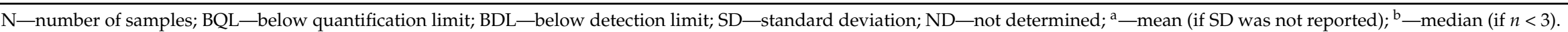


According to the latest literature, the total content of all selected elements was variable, however the results were generally in the same order of magnitude, except for As and Li (Table 6). Generally, most of determined elements had slightly higher contents than in the literature and the exceptions were $\mathrm{Cu}$ and Li. Significant excess levels of selected elements in comparison with the literature may be caused by dust residue deposition, which increased $\mathrm{Fe}, \mathrm{Ti}, \mathrm{As}, \mathrm{Pb}, \mathrm{Li}, \mathrm{Mo}$, and $\mathrm{V}$ concentrations of foliar tissue, what was confirmed in the washing process [26]. As samples were not washed prior to their homogenization, it explains higher content of $\mathrm{As}, \mathrm{Fe}, \mathrm{Mn}, \mathrm{Pb}, \mathrm{Mo}, \mathrm{Ni}$ and $\mathrm{Sb}$ found in our study than in the literature (Table 6). It was reported that field handling, transportation, and loading procedures were likely routes of soil contamination of commercial products [26].

Nevertheless, some observations in accordance with studied groups were similar to the literature data. According to kind (con palo or despalada), obtained results for total content of $\mathrm{Cu}, \mathrm{Ni}, \mathrm{Pb}$ and $\mathrm{Zn}$ corresponded to those obtained by Baran et al. [25], however the results for $\mathrm{Cd}, \mathrm{Fe}$ and $\mathrm{Mn}$ showed an opposite trend. Authors similarly reported the higher content of $\mathrm{Cr}$ and $\mathrm{Zn}$ and lower of $\mathrm{Mn}$ in Paraguayan yerba mate than those originating from Argentina [25]. According to origin, the highest content of Mn and Co in Argentinean samples, the lowest content of Mn and Co in Paraguayan samples and the lowest content of Fe, Ni and Zn in Brazilian samples were reported by Pozebon et al. [20]. According to the composition, samples of pure yerba mate contained higher content of $\mathrm{Mn}, \mathrm{Fe}, \mathrm{Al}, \mathrm{Ni}, \mathrm{As}, \mathrm{Co}$ and Mo than yerba mate with additives $(n=34)$, which contained more $\mathrm{Zn}, \mathrm{Cu}, \mathrm{Sb}$, Se, $\mathrm{Pb}$ and $\mathrm{Hg}$. Nevertheless, no significant data have been found in the literature evaluating the influence of additives on the elemental composition of yerba mate. It is worth adding that the results of the total elemental content in the context of the whole population of yerba mate samples were similar to those in the literature, except for the aforementioned exceptions $[11,23]$.

\subsection{Spearman's Rank Correlation Test}

The Spearman's rank correlation coefficient $\left(r_{s}\right)$ was used to describe the pairwise associations between total and extractable content of elements in yerba mate samples. The plot of the Spearman's correlation matrix of elements was presented in Figure S1.

For total content of 16 elements, there were no strong positive $\left(r_{s} \geq 0.7\right)$ nor strong negative correlations $\left(r_{\mathrm{s}} \leq-0.7\right)$. Moderate positive correlations $\left(0.4 \leq \mathrm{r}_{\mathrm{s}}<0.7\right)$ were observed between $\mathrm{Zn} / \mathrm{Cd}, \mathrm{Mn} / \mathrm{Co}, \mathrm{Zn} / \mathrm{Fe}, \mathrm{Li} / \mathrm{Al}, \mathrm{Ni} / \mathrm{Mn}, \mathrm{Pb} / \mathrm{Cu}, \mathrm{Cu} / \mathrm{Al}, \mathrm{Pb} / \mathrm{Al}, \mathrm{Pb} / \mathrm{Li}$, $\mathrm{Mn} / \mathrm{Cr}, \mathrm{Ni} / \mathrm{Co}, \mathrm{Li} / \mathrm{Fe}, \mathrm{Zn} / \mathrm{Li}$ and $\mathrm{Fe} / \mathrm{Al}$. Other positive correlations, which were statistically significant $(p<0.05)$, were weak $\left(r_{\mathrm{S}}<0.4\right)$. In turn, moderate negative correlation $\left(-0.7 \leq \mathrm{r}_{\mathrm{S}}<-0.4\right)$ was observed between the pairs: $\mathrm{Li} / \mathrm{Co}, \mathrm{Cu} / \mathrm{Co}, \mathrm{Pb} / \mathrm{Co}, \mathrm{Co} / \mathrm{Al}$ and $\mathrm{Mn} / \mathrm{Li}$. Other negative correlations, which were statistically significant, were weak $\left(\mathrm{r}_{\mathrm{s}}>-0.4\right)$. In the literature, positive correlations were also reported for $\mathrm{Ni} / \mathrm{Mn}(0.78)$, $\mathrm{Pb} / \mathrm{Cu}(0.71)$ [25] and $\mathrm{Al} / \mathrm{Pb}(0.55)$ [26]. For extractable content of 15 elements (without $\mathrm{Cr}$ ), there were two pairs of elements almost fully positive correlated $\left(\mathrm{r}_{\mathrm{s}} \geq 0.9\right)$ : $\mathrm{Mn} / \mathrm{Al}$ and $\mathrm{Cu} / \mathrm{Al}$. Strong positive correlations $\left(0.7 \leq \mathrm{r}_{\mathrm{s}}<0.9\right)$ were observed between $\mathrm{Fe} / \mathrm{Cu}, \mathrm{Ni} / \mathrm{Al}$, $\mathrm{Ni} / \mathrm{Mn}, \mathrm{Fe} / \mathrm{Al}, \mathrm{Ni} / \mathrm{Fe}, \mathrm{Ni} / \mathrm{Cu}, \mathrm{Mn} / \mathrm{Cu}, \mathrm{Fe} / \mathrm{Cd}$ and $\mathrm{Zn} / \mathrm{Fe}$, while moderate positive correlations $\left(0.4 \leq \mathrm{r}_{\mathrm{s}}<0.7\right)$ were observed between the following pairs: $\mathrm{Mn} / \mathrm{Fe}, \mathrm{Cu} / \mathrm{Cd}, \mathrm{Zn} / \mathrm{Cu}$, $\mathrm{Zn} / \mathrm{Cd}, \mathrm{Cd} / \mathrm{Al}, \mathrm{Ni} / \mathrm{Cd}, \mathrm{Zn} / \mathrm{Ni}, \mathrm{Zn} / \mathrm{Al}, \mathrm{Zn} / \mathrm{Mn}$ and $\mathrm{Mn} / \mathrm{Cd}$. All statistically significant negative correlations $(\mathrm{Li} / \mathrm{Co}$ and $\mathrm{Pb} / \mathrm{Mn})$ were weak $\left(\mathrm{r}_{\mathrm{s}}>-0.4\right)$. The $\mathrm{r}_{\mathrm{s}}$ coefficient was also calculated between total and extractable content, however there were no strong positive $\left(r_{s} \geq 0.7\right)$ nor strong and moderate negative correlations $\left(r_{s} \leq-0.4\right)$. Moderate positive correlations $\left(0.4 \leq \mathrm{r}_{\mathrm{S}}<0.7\right)$ were observed for total and extractable of $\mathrm{Pb}, \mathrm{As}, \mathrm{Sb}, \mathrm{Mn}$, Co and $\mathrm{Ni}\left(\mathrm{r}_{\mathrm{S}}=0.39\right)$. Moreover, positive correlation for total and water extractable content of $\mathrm{Mn}$, $\mathrm{Ni}$ and Co were also reported [22]. It is presumed that the higher concentrations as well as significant correlations of the total and extracted content, are related to the origin of these elements, which is dust residue deposition. It was confirmed that the higher contents of some elements in foliar tissue of yerba mate (Ilex paraguariensis) came from surface deposition of soil dust [26]. In the case of other elements, the $r_{s}$ coefficient was not significant statistically 
$(p<0.05)$ between their total and extractable content. In turn, moderate positive correlation was also observed in the following pairs: $\mathrm{Mn}(\mathrm{ext}) / \mathrm{Ni}($ total), $\mathrm{Ni}(\mathrm{ext}) / \mathrm{Mn}($ total $)$ and $\mathrm{Zn}(\mathrm{ext}) / \mathrm{Cd}$ (total), while weak positive correlation for $\mathrm{Co}(\mathrm{ext}) / \mathrm{Cr}$ (total), $\mathrm{Al}(\mathrm{ext}) / \mathrm{Mn}$ (total), $\mathrm{Fe}(\mathrm{ext}) / \mathrm{As}($ total), $\mathrm{As}(\mathrm{ext}) / \mathrm{Fe}$ (total), $\mathrm{Al}($ ext)/Ni(total), $\mathrm{Sb}(\mathrm{ext}) / \mathrm{Mn}$ (total), $\mathrm{Sb}(\mathrm{ext}) / \mathrm{Cd}$ (total), $\mathrm{Co}($ ext $) / \mathrm{Mn}$ (total), Cd(ext)/Se(total), Li(ext)/Se(total), Cu(ext)/Mn(total), As(ext)/Sb(total). There were also observed weak negative correlations between the pairs: $\mathrm{Mn}(\mathrm{ext}) / \mathrm{Li}($ total), $\mathrm{Mn}($ ext) $/ \mathrm{Zn}$ (total), $\mathrm{Pb}$ (ext)/Mn(total), and $\mathrm{Cu}($ ext)/Li(total) (Figure S1). Significantly high correlations between $\mathrm{Zn}$ and $\mathrm{Cd}$ may be associated with their chemical similarities [23], while other correlations (e.g., Fe/As) may indicate that these elements came from the common source (e.g., soil dust) [26].

\subsection{Principal Component Analysis (PCA)}

The results, obtained in the ICP OES analysis, were subjected to analysis by principal component analysis (PCA). Two components described $99.6 \%$ variability of the results of total concentration of 16 elements $(n=928$ of single results for 58 digested samples of yerba mate) and $99.8 \%$ variability of the results of extractable concentration of 15 elements ( $n=870$ of single results for 58 samples of yerba mate extracted with $\mathrm{H}_{3} \mathrm{PO}_{4}$ solution). In both cases, all samples were cumulated in one group (at the point +1.0 of the PC1 axis and it was distributed along the PC2 axis, from -0.2 to 0.3 ). According to this, it is clearly indicated that samples were similar in the elemental composition (both in accordance with total and extractable content). In the case of total content of 16 elements, 11 samples could be distinguished from the group, nos. 7, 14, 19, 29, 32, 33, 35, 36, 39, 43, 53, and most of them were paired as followed: $29+35,32+33$ (both pairs were Brand D), $39+43$ (both samples were Brand E) and $7+53$. What is more, samples nos. 32 and 33 were the same product (D3), collected both as a $500 \mathrm{~g}$ pack (no. 32) and a $50 \mathrm{~g}$ test sample (no. 33). The differentiation in terms of the total content of elements may be due to the additives (except samples nos. 7, 29 and 36 were pure yerba mate). Moreover, half of the Brand D samples (nos. 29, 32, 33 and 35) is also distinct. In the case of extractable content of 15 elements, only five samples could be distinguished from the group, nos. 9, 19, 29, 34, 35. The only pair $(34+35)$ was the same product (D4), collected both as a $500 \mathrm{~g}$ pack (no. 34) and a $50 \mathrm{~g}$ test sample (no. 35). As in the case of the total content, differentiations may be related to the additives (except sample no. 29). Only samples nos. 19, 29 and 35 were differed from the group in both contents, however their only common factor is being test samples.

The PCA for total and extractable content did not show any significant individual differences between the studied samples. Due to this, the percentages of extraction were additionally subjected to analysis by the PCA, however the data were reduced to nine elements only ( $n=490$ of single results for 58 samples), whose results were BQL for $<20 \%$ of all samples. Reduced data represented $93.9 \%$ of all results. The $70.4 \%$ variability of results was described by two components (Figure 2). For easy identification, samples were colored and divided in accordance with origin, type, composition and brand.

Two groups of samples could be formed (Figure 2). According to the country of origin, the Argentinian samples were distributed mainly in group 1, however samples nos. 3, 47, 50,52 and 53 were in group 2 . A substantial similarity between samples was visible for two brands: Brand A (except for sample no. 3) and Brand F (except for sample no. 47). In turn, the Brazilian samples were distributed between both groups ( 7 and 11 samples in group 1 and 2, respectively), however two samples (nos. 19 and 26) were significantly separated. A substantial difference between the two brands was visible in the case of the Brazilian yerba mate. Brand E samples were on the positive part of the PC2 axis (except for sample no. 36), while the Brand C samples were usually on the negative part of the PC2 axis (except for samples nos. 19 and 26). The Paraguayan samples were generally in group 2, however samples nos. 7, 10, 11 were out of the group. Moreover, the Brand D samples were on the negative part of the PC2 axis (except for sample no. 28, which was separated). 


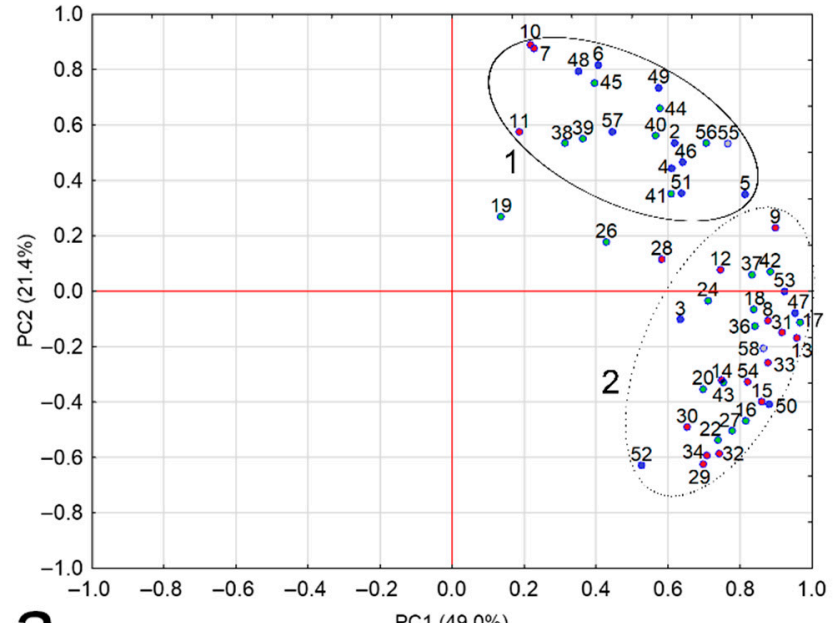

a

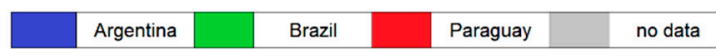

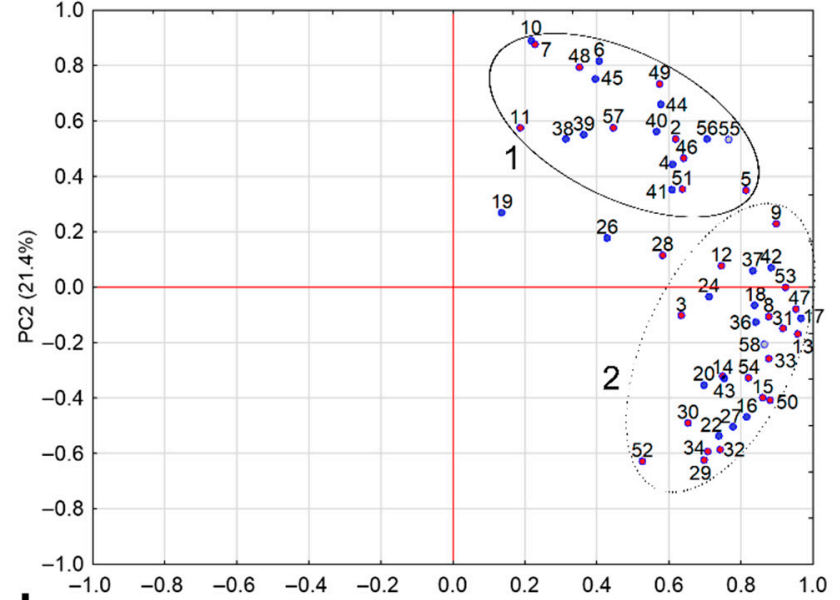

b

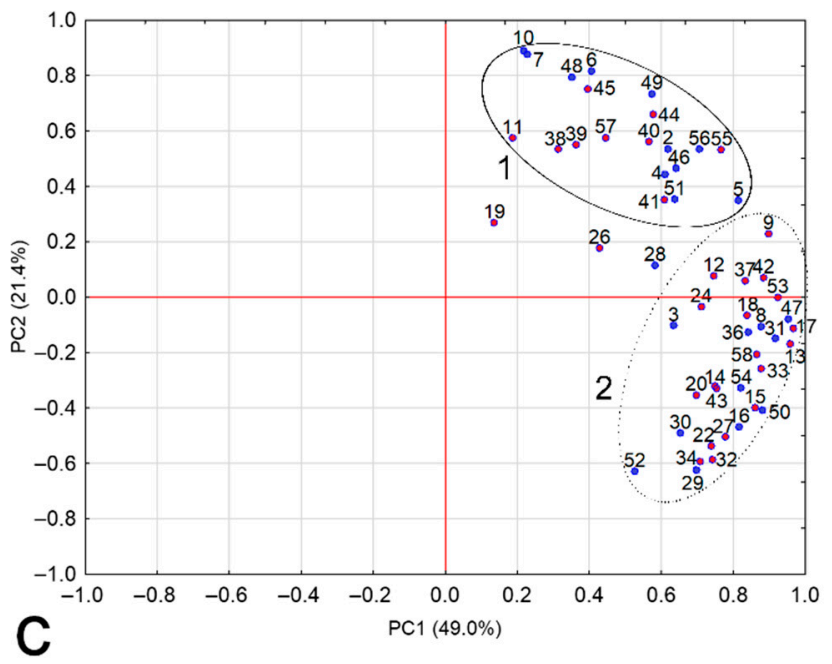

con palo

despalada

no data

C

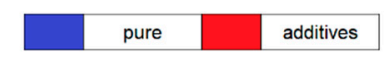

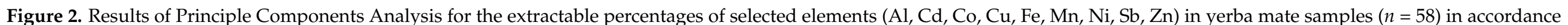
with (a) origin, (b) kind, and (c) composition. The 70.4\% variability of the results was described by two components (PC1, PC2). 
According to the kind of yerba mate, the con palo samples were distributed between both groups in the ratio 1:2 (9 and 18 samples in group 1 and 2, respectively) while despalada samples were distributed proportionally between both groups (10 and 11 samples in group 1 and 2, respectively). According to the composition (purity), samples were also distributed between both groups. Pure yerba mate samples were distributed proportionally between both groups, with 11 and 10 samples in group 1 and 2, respectively. In turn, nine and 20 samples of yerba mate with additives were distributed in group 1 and 2, respectively. Therefore, the PCA for the extraction percentages did not indicate any significant order in terms of the type (type) or composition (purity) of the yerba mate samples. Nevertheless, selected products, which were collected twice (a $500 \mathrm{~g}$ pack and a $50 \mathrm{~g}$ test samples), were generally distributed in the same group, except samples of B5 (nos. 11 and 12), and H1 (nos. 51 and 52).

The PCA results, such as the lack of a clear grouping of samples according to the country of origin, type (kind) or composition (purity), are partially confirmed by the latest literature data. Although the difference in elemental composition of yerba mate, indicated by the multidimensional statistical analysis, was defined as a geographical factor [20,22,28], it should be linked with the soil parent material where plants were cultivated [26]. This observation was also reported when the Brazilian samples from three different states were studied [22].

\section{Conclusions}

New methods of single-element speciation analysis have been applied for the first time to 58 commercial samples of yerba mate. As expected, the results of arsenic and iron species were comparable with those obtained for several samples in our preliminary studies $[12,13,17]$. By comparing the content of selected essential trace and potentially toxic elements obtained with two different procedures of sample preparation (digestion, extraction), it was shown that non-extractable content predominated in yerba mate, especially for iron (approx. 92\%). According to this, the determination of the arsenic and iron species as well as extractable content must be assessed in the context of the total content of these elements since the elements were built into the plant tissues during the growth stage. The occurrence of selected As and Fe species in yerba mate as well as occasionally the high content, are accidental rather than related to studied factors, i.e., country of origin, kind, composition or packing. What is more, no significant differences were noticed between the yerba mate products packaged in Poland and those packaged in South American countries. Probably the soil which was used for the cultivation of Ilex paraguariensis, is the main factor influencing the elemental composition, and not the country of origin as previously thought. In the future perspective, new methods of multi-element speciation analysis as well as an appropriate preparation procedure of this sample matrix should be developed to obtain more information about the origin, type and composition of yerba mate.

Supplementary Materials: The following are available online at https:/ / www.mdpi.com/article / 10.3390 / foods10122925/s1, Table S1. Results of spiked recovery in standard addition method (two sample solutions, P1 and P2, obtained in ultrasound-assisted extraction were spiked with two concentrations of mixed standard solution); Table S2. Results of spiked recovery in standard addition method (two sample solutions, P1 and P2, obtained in microwave-assisted digestion were spiked: Figure S1. The Spearman's correlation matrix of studied elements for total content and extractable content (without $\mathrm{Cr}$, details in text). Statistically significant coefficients $(p<0.05)$ are bolded and marked by asterisks.

Author Contributions: Conceptualization J.P. and P.N.; methodology P.N.; validation J.P; investigation J.P and A.O.; data curation J.P.; writing-original draft J.P. and A.O.; writing-review \& editing P.N.; funding acquisition J.P. All authors have read and agreed to the published version of the manuscript.

Funding: This research was funded by the European Social Fund under the Operational Program Knowledge Education Development grant number POWR.03.02.00-00-I026/16. 
Data Availability Statement: All data presented in the article are available from the corresponding author.

Conflicts of Interest: The authors declare no conflict of interest.

\section{References}

1. Pardinho, R.; Vecchia, P.D.; Mendes, A.; Bizzi, C.; Mello, P.; Duarte, F.; Flores, E. Determination of toxic elements in yerba mate by ICP-MS after diluted acid digestion under $\mathrm{O}_{2}$ pressure. Food Chem. 2018, 263, 37-41. [CrossRef] [PubMed]

2. Cardozo, E., Jr.; Morand, C. Interest of mate (Ilex paraguariensis A. St.-Hil.) as a new natural functional food to preserve human cardiovascular health-A review. J. Funct. Foods 2016, 21, 440-454. [CrossRef]

3. Bastos, M.C.; Cherobim, V.; Reissmann, C.; Kaseker, J.F.; Gaiad, S. Yerba mate: Nutrient levels and quality of the beverage depending on the harvest season. J. Food Compost. Anal. 2018, 69, 1-6. [CrossRef]

4. Verbruggen, N.; Hermans, C.; Schat, H. Mechanisms to cope with arsenic or cadmium excess in plants. Curr. Opin. Plant Biol. 2009, 12, 364-372. [CrossRef]

5. Schmite, B.; Bitobrovec, A.; Hacke, A.; Pereira, R.; Weinert, P.; dos Anjos, V. In vitro bioaccessibility of $\mathrm{Al}, \mathrm{Cu}, \mathrm{Cd}$, and Pb following simulated gastro-intestinal digestion and total content of these metals in different Brazilian brands of yerba mate tea. Food Chem. 2019, 281, 285-293. [CrossRef]

6. Carelton, J. Final Report: Biogeochemistry of Arsenic in Contaminated Soils of Superfund Sites; Environmental Protection Agency: Washington, DC, USA, 2007.

7. Wolle, M.; Conklin, S.; Wittenberg, J. Matrix-Induced transformation of arsenic species in seafoods. Anal. Chim. Acta 2019, 1060, 53-63. [CrossRef] [PubMed]

8. Sánchez, M.; Sabio, L.; Gálvez, N.; Capdevila, M.; Dominguez-Vera, J. Iron chemistry at the service of life. IUBMB Life 2017, 69, 382-388. [CrossRef]

9. Podwika, W.; Kleszcz, K.; Krośniak, M.; Zagrodzki, P. Copper, Manganese, Zinc, and Cadmium in Tea Leaves of Different Types and Origin. Biol. Trace Elem. Res. 2017, 183, 389-395. [CrossRef] [PubMed]

10. Barbosa, J.; Motta, A.; Consalter, R.; Poggere, G.; Santin, D.; Wendling, I. Plant growth, nutrients and potentially toxic elements in leaves of yerba mate clones in response to phosphorus in acid soils. An. Acad. Bras. Cienc. 2018, 90, 557-571. [CrossRef]

11. Marcelo, M.; Martins, C.; Pozebon, D.; Dressler, V.; Ferrão, M. Classification of yerba mate (Ilex paraguariensis) according to the country of origin based on element concentrations. Microchem. J. 2014, 117, 164-171. [CrossRef]

12. Proch, J.; Niedzielski, P. In-spray chamber hydride generation by multi-mode sample introduction system (MSIS) as an interface in the hyphenated system of high performance liquid chromatography and inductivity coupled plasma optical emission spectrometry (HPLC/HG-ICP-OES) in arsenic species determination. Talanta 2019, 208, 120395. [CrossRef]

13. Proch, J.; Niedzielski, P. Iron species determination by high performance liquid chromatography with plasma based optical emission detectors: HPLC-MIP OES and HPLC-ICP OES. Talanta 2021, 231, 122403. [CrossRef]

14. Escudero, L.; Pacheco, P.; Gasquez, J.; Salonia, J. Development of a FI-HG-ICP-OES solid phase preconcentration system for inorganic selenium speciation in Argentinean beverages. Food Chem. 2015, 169, 73-79. [CrossRef]

15. Pereira, C.; Souza, A.; Oreste, E.; Cidade, M.; Cadore, S.; Ribeiro, A.; Vieira, M. Acid Decomposition of Yerba Mate (Ilex paraguariensis) Using a Reflux System for the Evaluation of $\mathrm{Al}, \mathrm{Ca}, \mathrm{Cd}, \mathrm{Cr}, \mathrm{Cu}, \mathrm{Fe}, \mathrm{K}, \mathrm{Mg}, \mathrm{Mn}, \mathrm{Na}, \mathrm{Pb}$ and $\mathrm{Zn}$ Contents by Atomic Spectrometric Techniques. J. Braz. Chem. Soc. 2016, 27, 685-693. [CrossRef]

16. Borges, A.; Bazanella, D.; Duarte, Á.; Zmozinski, A.; Vale, M.; Welz, B. Development of a method for the sequential determination of cadmium and chromium from the same sample aliquot of yerba mate using high-resolution continuum source graphite furnace atomic absorption spectrometry. Microchem. J. 2017, 130, 116-121. [CrossRef]

17. Proch, J.; Niedzielski, P. Multi-mode Sample Introduction System (MSIS) as an interface in the hyphenated system 2 HPLC-MSISICP-OES in simultaneous determination of metals and metalloids species. Anal. Chim. Acta 2021, 1147, 1-14. [CrossRef]

18. Schunk, P.; Kalil, I.; Pimentel-Schmitt, E.; Lenz, D.; de Andrade, T.; Ribeiro, J.; Endringer, D. ICP-OES and Micronucleus Test to Evaluate Heavy Metal Contamination in Commercially Available Brazilian Herbal Teas. Biol. Trace Elem. Res. 2015, 172, 258-265. [CrossRef]

19. Santos, L.; Neto, S.V.; Iozzi, G.; Jacob, S. Arsenic, cadmium and lead concentrations in Yerba mate commercialized in Southern Brazil by inductively coupled plasma mass spectrometry. Cienc. Rural 2017, 47. [CrossRef]

20. Pozebon, D.; Dressler, V.; Marcelo, M.; de Oliveira, T.; Ferrão, M. Toxic and nutrient elements in yerba mate (Ilex paraguariensis). Food Addit. Contam. B 2015, 8, 215-220. [CrossRef]

21. ANVISA. Regulamento Técnico Mercosul Sobre Limites Máximos de Contaminantes Inorgânicos em Alimentos (REVOGAÇÃO DAS RES. GMC N $N^{\circ}$ 102/94 e N³5/96); Mercosul, Ed.; Agência Nacional de Vigilância Sanitária: Brasília, Brazil, 2013; pp. 1-18.

22. Ulbrich, N.; do Prado, L.; Barbosa, J.; Araujo, E.; Poggere, G.; Motta, A.; Prior, S.; Magri, E.; Young, S.; Broadley, M. Multielemental Analysis and Health Risk Assessment of Commercial Yerba Mate from Brazil. Biol. Trace Elem. Res. 2021, 1-9. [CrossRef]

23. Olivari, I.; Paz, S.; Gutiérrez, Á.; González-Weller, D.; Hardisson, A.; Sagratini, G.; Rubio, C. Macroelement, trace element, and toxic metal levels in leaves and infusions of yerba mate (Ilex paraguariensis). Environ. Sci. Pollut. Res. 2020, 27, 21341-21352. [CrossRef] [PubMed] 
24. Da Costa, A.G.; Nogami, E.; Visentainer, J.; de Souza, N.; Garcia, E. Fractionation of Aluminum in Commercial Green and Roasted Yerba Mate Samples (Ilex paraguariensis St. Hil.) and in Their Infusions. J. Agric. Food Chem. 2009, 57, 196-200. [CrossRef] [PubMed]

25. Baran, A.; Gruszecka-Kosowska, A.; Kołton, A.; Jasiewicz, C.; Piwowar, P. Content and health risk assessment of selected elements in the Yerba mate (Ilex paraguariensis, St. hillaire). Hum. Ecol. Risk Assess. Int. J. 2017, 24, 1092-1114. [CrossRef]

26. Motta, A.; Barbosa, J.; Magri, E.; Pedreira, G.; Santin, D.; Prior, S.; Consalter, R.; Young, S.; Broadley, M.; Benedetti, E. Elemental composition of yerba mate (Ilex paraguariensis A.St.-Hil.) under low input systems of southern Brazil. Sci. Total Environ. 2020, 736, 139637. [CrossRef]

27. Magri, E.; Valduga, A.; Gonçalves, I.; Barbosa, J.; Rabel, D.; Menezes, I.; Nascimento, P.; Oliveira, A.; Corrêa, R.; Motta, A. Cadmium and lead concentrations in yerba mate leaves from agroforestry and plantation systems: An international survey in South America. J. Food Compost. Anal. 2021, 96, 103702. [CrossRef]

28. Bragança, V.; Melnikov, P.; Zanoni, L. Trace Elements in Different Brands of Yerba Mate Tea. Biol. Trace Elem. Res. 2011, 144, 1197-1204. [CrossRef] [PubMed] 